\title{
DRAFT
}

\section{Guidelines for Generators of Hazardous Chemical Waste at LBL}

\author{
and
}

\section{Guidelines for Generators of Radioactive and Mixed Waste at LBL}

\author{
Revision 0 \\ July 1991
}

Environment, Health and Safety Division

Lawrence Berkeley Laboratory

University of Califormia

Berkeley, CA 94720

\section{MASTER}

Prepared for the U.S. Department of Energy under Contract No. DE-AC03-76SF00098. 


\section{Contents}

Guidelines for Generators of Hazardous Chemical Waste at LBL

1. Introduction

CHEM-1

2. Governing Documents

CHEM-3

3. Definitions

4. Identification

CHEM-3

5. Segregation

CHEM-6

6. Separation

CHEM-8

7. Packaging (Containers)

CHEM-9

8. Labeling

CHEM-11

9. Transferring Your Waste to the HWHF

CHEM-11

10. Characterization

CHEM-14

CHEM-16

List of Figures

Figure 1. Flowchart for hazardous waste at LBL

CHEM-2

Figure 2. Record of Waste Accumulation form

CHEM-5

Figure 3. Hazardous Waste Label

CHEM-13

Figure 4. Waste Organic Solvents tag

CHEM-15

Figure 5. Laboratory Waste Analysis Request Form

CHEM-19

Guidelines for Generators of Radioactive and Mixed Waste at LBL

1. Introduction

RAD-1

2. Governing Documents

RAD-2

3. Definitions

RAD-4

4. Characterization

RAD-6

5. Requirements Applying to All Radioactive and Mixed Wastes

RAD-12

6. Requirements Unique to Each Waste Stream

RAD-17

List of Figures

Figure 1. Flowchart for hazardous waste at LBL

RAD-3

Figure 2. Record of Waste Accumulation form

RAD-9

Figure 3. Laboratory Waste Analysis Request Form

RAD-11

Figure 4. Radioactive Waste tag (front side only)

RAD-15

\section{Appendices}

Appendix A: Hazardous Waste Disposal Requisition

Appendix B: Profiling Wastes

B-1

Appendix C: Who to Call for Further Information

C-1

Appendix D: Forms

D-1 


\section{Guidelines for Generators of Hazardous Chemical Waste at LBL}




\section{Contents}

Guidelines for Generators of Hazardous Chemical Waste at LBL

1. Introduction

CHEM-1

2. Governing Documents

CHEM-3

3. Definitions

CHEM-3

4. Identification

CHEM-6

5. Segregation

CHEM-8

6. Separation

CHEM-9

7. Packaging (Containers)

CHEM-11

8. Labeling

9. Transferring Your Waste to the HWHF

CHEM-11

10. Characterization

List of Figures

Figure 1. Flowchart for hazardous waste at LBL

CHEM-2

Figure 2. Record of Waste Accumulation form

CHEM-5

Figure 3. Hazardous Waste Label

CHEM-13

Figure 4. Waste Organic Solvents tag

CHEM-15

Figure 5. Laboratory Waste Analysis Request Form

CHEM-19 


\section{Guidelines for Generators of Hazardous Chemical Waste at LEL}

\section{Section 1: Introduction}

The purpose of this document is to provide the acceptance criteria for the transfer of hazardous chemical waste to LBL's Hazardous Waste Handling Facility (HWHF).

Hazardous chemical waste is a necessary byproduct of LBL's research and technical support activities. This waste must be handled properly if LBL is to operate safely and provide adequate protection to staff and the environment. These guidelines describe how you, as a generator of hazardous chemical waste, can meet LBL's acceptance criteria for hazardous chemical waste.

All hazardous chemical waste generated by LBL research activities is transferred to the HWHF, or packaged for direct shipment to the disposal site (for Buildings 1, 3, and 934). The HWHF is managed by the Environment, Health and Safety (EH\&S) Division. The waste may be treated, if necessary, and packaged for shipment to the proper disposal facility.

If you use hazardous chemicals, the requirements listed in these guidelines apply to you. These requirements must be followed for proper disposal of hazardous waste. EH\&S personnel will check your waste to make sure it meets the acceptance criteria listed in these guidelines. If the waste does not meet the criteria, the EH\&S representative will provide advice on how to meet the criteria.

Figure 1 shows the flowchart for hazardous waste at LBL.

These guidelines do not apply to radioactive wastes, including wastes that contain both radioactive and hazardous materials (called mixed waste). For information on radioactive and mixed wastes, see the Guidelines for Generators of Radioactive and Mixed Waste at LBL (part of this document). The guidelines also do not apply to purely medical and biohazardous wastes. For information on proper handling and disposal of medical and biohazardous wastes, see PUB-3095, Medical and

Biohazara'sus Waste Generator's Guide (currently in draft form).

The rest of these guidelines are divided into the following sections:

$\begin{array}{ll}\text { - } & \text { Governing Documents } \\ \text { - Identification } \\ \text { - Segregation } \\ \text { - Separation }\end{array}$

- Packaging

- Labeling

- Transfer of Waste to HWHF

- Characterization 


\section{Generator's Guide to Hazardous Waste Disposal at LBL}

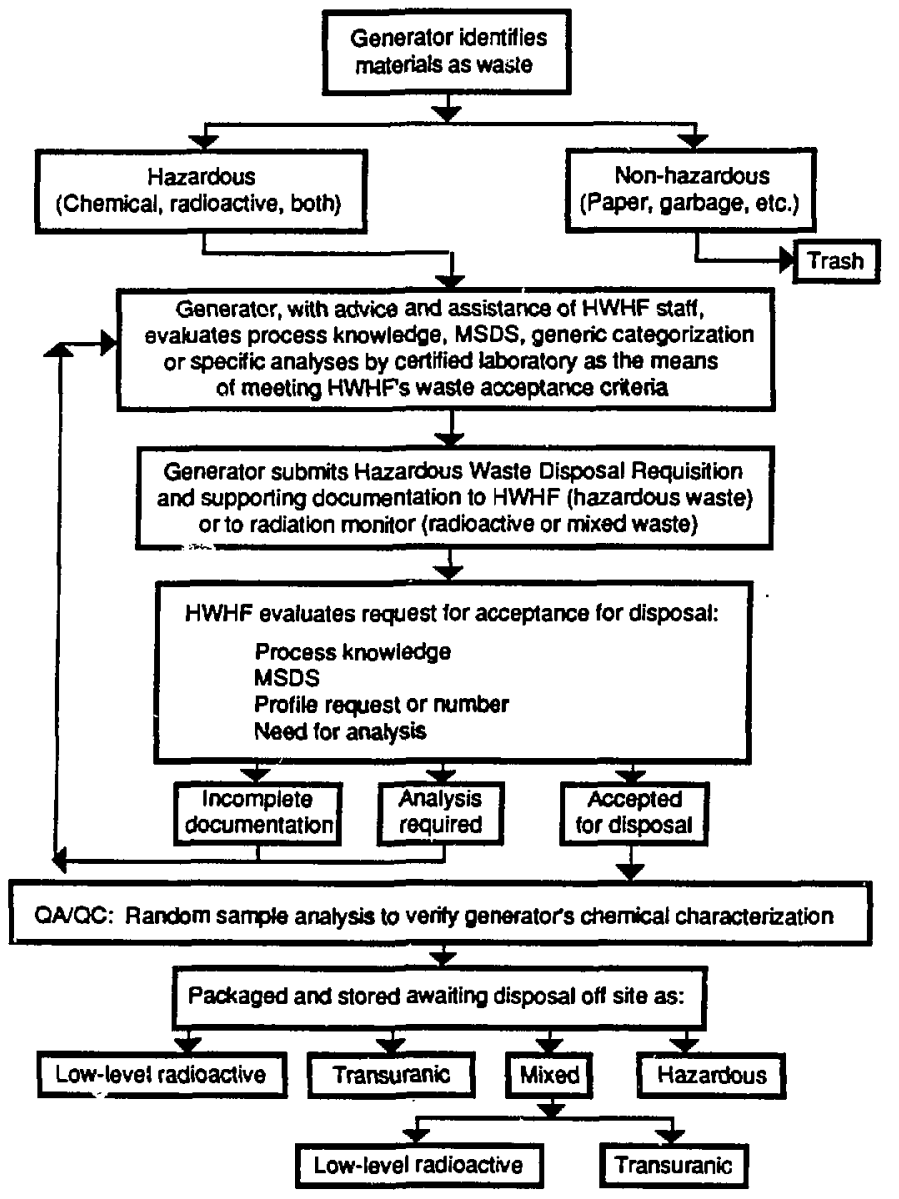

Figure 1. Flowchart for hazardous waste at LBL 
The Governing Documents and Definitions sections provide general guidelines and regulations applying to the handling of hazardous chemical wastes. The remaining sections provide details on how you can prepare your waste properly for transport and disposal. They are correlated with the steps you must take to properly prepare your waste for pickup.

\section{Section 2: Governing Documents}

The following documents appiy to the handling of hazardous chemical wastes at LBL:

- United States Environmental Protection Agency, 40 Code of Federal Regulations (40 CFR)

- United States Department of Transportation, 49 Code of Federal Regulations (49 CFR)

- Occupational Safety and Health Administration, 29 Code of Federal Regulations (29 CFR)

- United States Department of Energy Orders

- California Code of Regulations (CCR) Title 22

- California Department of Health Services Hazardous Waste Control Law (excerpt from Health and Safety Code, Division 20)

- EPA SW-846 (an EPA manual for solid waste analysis)

- PUB-3000, the LBL Health and Safety Manual

- LBL's Waste Analysis Plan, Pub-5309 (May 5, 1991 issue)

\section{Section 3: Definitions}

\section{Hazardous wastes are}

- wastes listed in the California Code of Regulations (22 CCR 66680) and the Code of Federal Regulations (40 CFR Part 261)

- wastes that exhibit one or more of the criteria for identification of "hazardous waste" (22 CCR 66693-66723). These criteria are

- toxicity

- persistent and bioaccumulative effect

- ignitibility

- reactivity

- corrosivity

- radioactive mixed wastes (materials that contain both hazardous chemical and radioactive wastes)

- wastewater that exceeds sanitary-sewer discharge limits. 
Extremely hazardous substances are any of 406 chemicals identified by EPA on the basis of toxicity and listed under SARA Title III.

Ignitable wastes include liquids with a flash point of less than $140^{\circ} \mathrm{F}$, solids that ignite spontaneously through absorption of moisture or through friction and burn vigorously, flammable gases, and oxidizers.

Identification is the description of the waste in a container. When you fill out the Hazardous Waste Disposal Requisition, you identify your waste.

A waste generator is the individual or operation responsible for actually generating the hazardous waste within an organization. LBL as a whole is viewed as a waste generator by environmental regulatory agencies. Within LBL, each researcher, laboratory, shop, and facility, as a potential point of origin for hazardous waste, is a waste generator.

A waste-generating organization is the program, facility, or group that generates the waste.

A waste stream is waste generated from an industrial process or application, laboratory experiment, or routine laboratory procedure, with roughly constant and unchanging hazardous and/or radioactivity characteristics.

Segregate in this document means "do not mix" chemically unrelated or incompatible materials in the same container; each SAA container must contain waste of only one hazard category.

Separate mieans "set apart physically" in this document.

Characterization refers to the detailed documentation necessary to certify that the waste is what it is claimed to be. Characterization can include knowledge of process (see definition below), required analyses, or written documentation (log books, formulas, etc.).

Knowledge of process refers to the ability of the generator to characterize waste on the basis of knowing the processes by which the waste was generated. It also includes being able to verify the characterization with the documented procedures used and data accumulated during the waste-generation process. (See the Record of Waste Accumulation form, Figure 2, for an example of a data-accumulation log.)

Certification means that the person who signs his or her name on the Hazardous Waste Disposal Requisition (see Appendix A) says (or certifies) that the contents of the waste package are described exactly and correctly by the requisition. This description (and the signature) are legally binding. 


\section{LAWRENCE BERKELEY LABORATORY RECORD OF WASTE ACCUMULATION}

\begin{tabular}{|c|c|c|c|}
\hline$A B A C E$ & DESCRIPTTONOFWHATWASADDED & AMOUNT & INTTALS \\
\hline $6 / / / 91$ & Ethyl Acotate & $500 \mathrm{ML}$ & SBS \\
\hline 67 & Methanol & $.5 \mathrm{~L}$ & we \\
\hline $6 / 8$ & Hexane & $1.0 \mathrm{~L}$ & RAJ \\
\hline $6 / 10$ & Acotone & $1.0 \mathrm{~L}$ & no \\
\hline $6 / 15$ & Acatone & $.2 \mathrm{~L}$ & SBS \\
\hline $6 / 15$ & Ethyl Acotate & $.1 \mathrm{~L}$ & KOWN \\
\hline$-6 / 46-$ & Acotone & $100411-$ & RAL \\
\hline $6 / 20$ & Methanol & $.2 \mathrm{~L}$ & wC \\
\hline $6 / 21$ & Acotone & $2.0 \mathrm{~L}$ & we \\
\hline $6 / 23$ & Ethyl Acotate & $2.0 \mathrm{~L}$ & wo \\
\hline $6 / 23$ & Hexane & $1.2 \mathrm{~L}$ & ran \\
\hline $7 \pi$ & Acotone & $.5 \mathrm{~L}$ & SES \\
\hline $7 / 1$ & Acatone & $1000 \mathrm{ML}$ & WC \\
\hline $7 / 2$ & Ethyl Acotate & $1.0 \mathrm{~L}$ & SBS \\
\hline $7 / 2$ & Acetone & $3.0 \mathrm{~L}$ & RAN \\
\hline $7 / 3$ & Acothe Mothand & $0.2 \mathrm{~L}$ & $\operatorname{LOMN}$ \\
\hline & 715 & & \\
\hline & & & \\
\hline & & & \\
\hline & & & \\
\hline & & & \\
\hline & & & \\
\hline & & & \\
\hline & & & $\cdot$ \\
\hline & & & \\
\hline
\end{tabular}

Figure 2. Record of Waste Accumulation form. See Appendix D for full-sized form. 
Treatment means any method, technique, or process designed to change the physical, chemical, or biological character or composition of any hazardous waste. (This definition is taken from 40 CFR 260.10 and 22 CCR 66216.) Neutralization and dilution are examples of processes that are considered treatments by Federai and state regulations.

Satellite Accumulation Areas (SAAs) are areas in individual laboratories, shops, arid other facilities officially set aside for the accumulation of waste, not to exceed $100 \mathrm{~kg} /$ month of hazardous waste or $1 \mathrm{~kg} /$ month of extremely hazardous waste. The area must be in the line of sight of the work area. Waste can accumulate in SAAs for up to 275 days ( 90 days less than a year). Because of the need to segregate waste into specific categories, a different site must be established for each class of waste stream for each facility/laboratory. For example, a given laboratory could have one SAA for solvents and another for hazardous chemicals. PUB-3094, Guidelines for Satellite Accumulation Areas (SAAs) at $L B L$, provides details on SAAs.

Waste Accumulation Areas (WAAs) are officially designated areas for the accumulation and storage of waste for sites generating more than $100 \mathrm{~kg} /$ month of all types of hazardous waste. Specific regulations apply to WAAs, including security, posting, labeling and signage, a 60-day time limit for storage, and the requirement that the time period starts when any amount of waste begins to accumulate. PUB-3093, Guidelines for Waste Accumulation Areas (WAAs) at LBL, provides details on WAAs.

\section{Section 4: Identification}

Hazardous waste must be identified chemically, by hazard sategory, amount, and physical state. Waste that is not identified properly canno! be accepted for disposal.

All constituents in mixtures, solid and liquid, must be identified and their concentrations stated. A pH measurement will be accepted only as a measure of concentration for identification if it is between 3 and 10. Beycind these limits, waste materials should be considered corrosive. Acids and bases other than pure material in its original container must be analyzed and their strengths given in normality, molarity, or weight percent.

Trade-name chemicals are required to have a Material Safety Data Sheet (MSDS) attached to the waste container. 


\subsection{Methods of Identification}

Identify waste materials on the Hazardous Waste label (Figure 3 on Page 12) and on each separate waste container in one of three ways:

1. Chemical name or structural formula and concentrotion. To identify an organic compound as a strichiometric formula is noi adequate. If the material is a mixture, provide con_untrations of all constituents. Concentrations may be stated in molarity, percent by weight or volume (percent is assumed to be by weight unless volume is stated), weight per volume (grams or milligrams per liter, pounds per gallon), or parts per million or billion.

2. Manufacturer and specific product (for example, trade name or number, catalog number, etc.), including all hazardous materials listed in the MSDS for the specific product. Manufacturers of potentially hazardous materials are required by law to provide MSDSs, including a list of all potentially hazardous ingredients. If no hazardous ingredients are identified on the MSDS, attach a photocopy of page 1 of the MSDS to the Hazardous Waste container. By law, OSHA requires users of these products to keep files of MSDSs in the work area for employee reference. Chemical identification information of manufactured products may also be found in the Aldrich Catalog of Fine Chemicals,. the NIOSH Registry of Toxic Effects of Chemical Substances, and The Merck Index: An Encyclopedia of Chemicals, Drugs, and Biologicals.

3. Complete generic description of material only if the material is a mixture with a well-known standard composition. The description should indicate whether the material is new, has exceeded shelf life, is spent, etc. If the material is a process waste, such as a cleaning agent or an etching bath, list all of the potential contaminants from the process in addi .on to the known constituents-for example, "chromic acid dip-tank waste with copper." For machine coolants, identify the metals for which the coolants were used. Analysis will be required for the metal coniaminants.

The generic description must be complete enough to adequately characterize the waste macerial. For example, "photochemicals" is insufficient because a minimum of three distinctly different baths are used in the simplest blackand-white developing process, and modern color processing requires a minimam of seven baths. The description must be more specific, such as "alkaline photo developer" or "photo fixer with chromate bleach." Specific analysis will be required ior these wastes, depending on the nature of the waste and the available means of disposal. "Mixed acid," "mixed solvents," etc., are not lizitimate generic identifications. They do not have any specific formulation at all. Acid and solvert? mixtures must be specified as stated above unior "Chemical name or structural formula," with each constituent chemically identified and its concentration given. 
Solvent-collection drums have no formulation and cann st be identified generically. Mixed solvents are incinerated, recycled, sold for fuel, or sent out for disposal, depending on the contaminants and level of contamination. Therefore, in addition to a description of the solvents contained in the drum, an analysis of volatile halogenated solvents is required for all solvent mixtures. Analysis of other hazardous contaminants may be required if there is any reason to believe that unlisted contaminants are present.

\section{Section 5: Segregation}

Certain wastes musi not be mixeủ for compelling safety and environmental reasons. The preparation and handling of hazardous materials for economical disposal as waste begins with segregation as the hazardous waste is generated. The simplest and most effective way you as a generator can reuuce waste disposal cc.3ts is to set up your operation to properly segregate your waste materials as they are collected. Segregation of waste also helps minimize hazardous waste. Avoid as much as possible "witch's brews" of improper hazardous mixtures that are prohibitively expensive to dispose of and often impossible to recycle. The following guidelines will help you to segregate your waste.

- Segrigate flammable waste solvents (acetone, alcohol, etc.) from halcgenated (containing chlorine, fluorine, bromine, or iodine) solvents. These hydrocarbon solvents can be recycled or incinerated if they are not contaminated with halides.

- Keep waste oil free of contamination by halogenated solvents. Do not mix electrical insulating.oils with other oils, chlorinated solvents, or water. Waste oil can be recycled or used as fuel if it is not contaminated.

- Keep acids and aciri plating solutions free of cyanides.

- Keep acids and caustics free of contamination with heavy metals and beryllium. Contaminated acid and caustic waste solutions must be segregated from uncontaminated acid and caustic waste solutions.

- Keep waste halogenated solvents free of nonhalogenated hydrocarbon solvents. Large volumes of each group can be redistilled and recycled individually.

Keeping waste materials segregated requires only a reasonable amount of forethought and effort, but requires it of every individua! in the operation. 


\section{Section 6: Separation}

\subsection{Set Aside an Area Appropriate for the Accumulation of Waste}

Label a container to receive each of your waste sireams. If your work area has a preexisting Satellite Accumulation Area (SAA) or Waste Accumulation Area (WAA), use it. If you plan to set up a WAA, you must notify HWHF staff for approval and guidance.

\subsection{Separate Radioactive from Nonradioactive Wastes}

Separate all materials contaminated with radioactive nuclides from all nonradioactive wastes. Radioactive wastes must have their own WAAs or SAAs. Radioactive materials require separate hardling. (All materials containing naturally occurring radioactivity, such as uranium and thorium, are considered radioactive.) Refer to the Guidelines for Generators of Radioactive and Mixed Waste at $L B L$ for details on handling radioactive and mixed wastes.

Separate nonradioactive hazardous wastes by chemical category, following these rules:

\subsubsection{Flammables}

- Separate all spontaneous ignition sources and explosives from everything else. Package separately in such a way as to contain and isolate any ignition that may occur. Explosives are not handled at the HWHF. Contact EH\&S for information on disposing of explosives. Potential explosives include picric acid and hydrocyanic acid. Appendix A provides detailed lists of potentially, explosive chemicals.

- Separate strong oxidizers from all fuels and package separately.

- Separate all extremely hazardous toxic chemical gases and compressed gases from potential fire hazards. Contact EH\&S if you have questions.

- Separate peroxide-forming chemicals from all other combustible materials. Package separately.

\subsubsection{Other Hazardous Wastes}

- Separate acids from bases and package separately.

- Separate all water reactives from everything else. Package separately; protect from water. Place a WATER REACTIVE warning on packages. 
- Separate extremely hazardous noncorrosive materials from corrosive materials.

- Separate halogenated solvents from nonhalogenated solvents.

- Separate waste oils from solvents.

- Separate extremely toxic chemicals and poisons from all other wastes.

See the Hazardous Waste Disposal Requisition (Appendix A) for further details.

\subsubsection{Compressed Gases and Pressurized Liquids}

Separate compressed gases and pressurized liquids from all other wastes. Prepare in the following manner where applicable:

- Remove all extraneous plumbing (excluding double valving) from cylinders before transporting the cylinders for disposal.

- Place safety caps on cylinders that require them.

- Separate gases into two categories: oxidizers and fuels. These are shipped separately.

- Analyze the contents of unknown cylinders before they are transported to the HWHF. This step is the responsibility of the generator. Call EH\&S (ext. 5251) for assistance.

- Place sample cylinders and disposable cylinders containing toxic or corrosive materials on pallets to prevent accidental valve breakage; then properly identify and tag them, and have them sent to the HWHF for storage and disposal.

- Separate all aerosol cans from other wastes.

- Place vendor-owned cylinders (Matheson, Air Products, Linde, etc.) on pallets and return them to Building 69 . A cylinder return tag must be filled out and attached to each cylinder identifying the generator and the contents of the cylinder. 


\section{Section 7: Packaging (Containers)}

Obtain and set up your waste containers based on the following rules:

\begin{tabular}{|l|l|l|}
\hline \multicolumn{1}{|c|}{ Waste Type } & \multicolumn{1}{|c|}{ Approved Container } & \multicolumn{1}{c|}{ How to Obtain } \\
\hline Liquid wastes (large quantities) & 55 -gal. DOE 17E drum & Contact EH\&S \\
Solid wastes (large quantities) & 55 -gal DOE 17H drum & Contact EH\&S \\
Small individual waste & Plastic tote box & Stores item 8115-66258 \\
containers & Double plastic bags & Stores item 8105 series \\
Asbestos & labeled ASBESTOS & (depending on size) \\
Mercury & Keep in original & \\
PCB-containing wastes & Containers & \\
\hline
\end{tabular}




\section{Section 8: Labeling}

Attach a Hazardous Waste label (Figure 3), available from EH\&S, to each of your hazardous chemical waste containers. The Hazardous Waste label identifies the contents of the container and specifies the amount of every waste constituent placed in it, including the identity of commercial products as well as chemical reagents.

Each collection container in your Waste Accumulation Area or Satellite Accumulation Area must have a Hazardous Waste label attached to it. Smaller containers to be packed into larger containers do not require a Hazardous Waste label, but the contents of each collection container must be identified on the container itself. See the Guidelines for Satellite Accumulation Areas (SAAs)at LBL (PUB-3094) and Guidelines for Waste Accumulation Areas (WAAs) at LBL (PUB-3093) for rules on how the containers must be stored.

\section{Collection Containers}

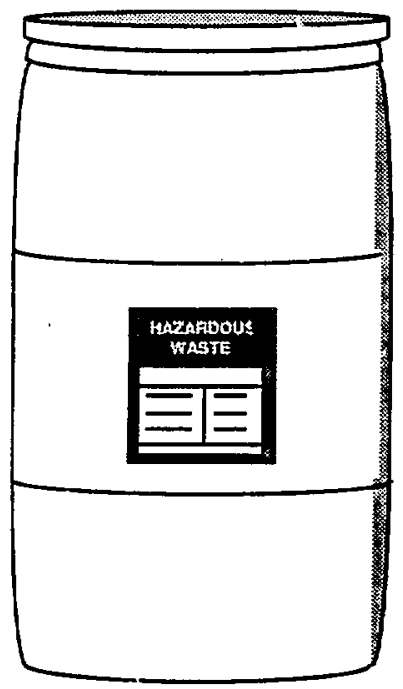

55-gallon drum

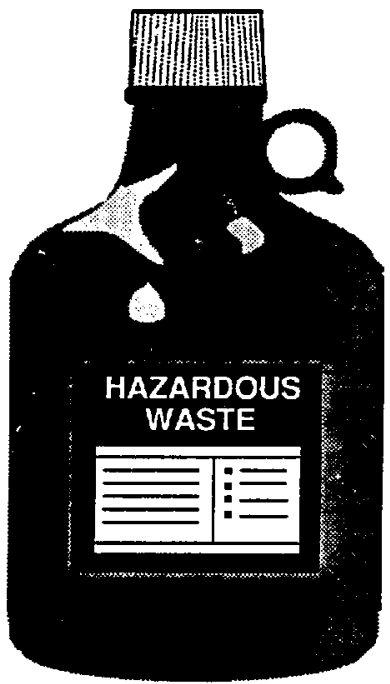

one-liter jug 


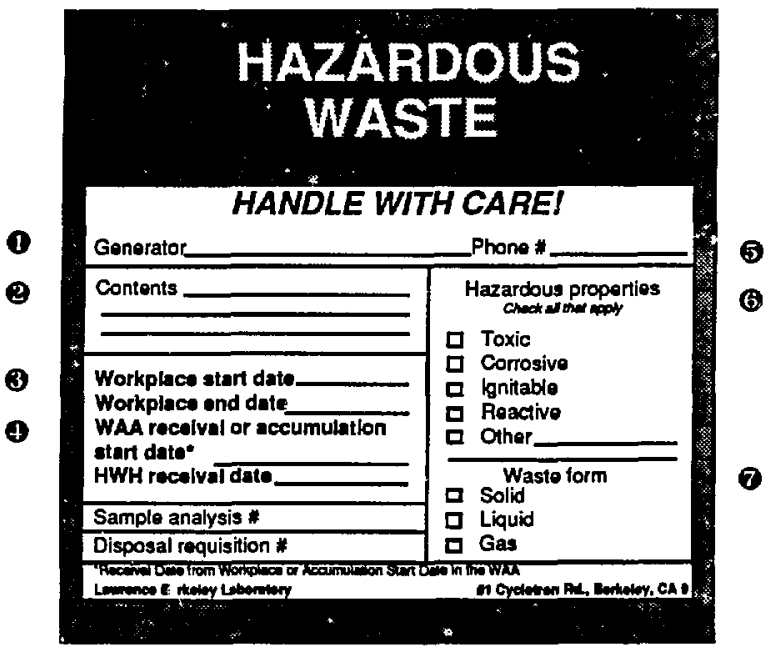

( Generator: Enter name and building of person generating the waste.

(2) Contents: Give chemical name, material name, or waste stream description. Describe composition of waste.

3 Workplace start date: Enter date waste is first placed in container (SAAs). Leave blank for WAAs.

Workplace end date: Fill in current date when container is sealed (SAAs). Leave blank for WAAs.

(4) WAA receival or accumulation start date: Enter date wi ste is first placed in container.

(3) Phone Number: Enter generator's LBL phone number.

(- Hazardous properties: Check appropriate boxes.

8 Waste form: Check appropriate box.

Figure 3. LBL Hazardous Waste label. 
Complete the following sections on the Hazardous Waste label. Write legibly, using a permanent ink marker.

- Generator's name and building
- Contents
Workplace start date (filled in when waste is first added to a container in
an SAA) or WAA receival or accumulation start date (filled in when
waste is first added to a container in a WAA)
Hazardous properties
Waste form

Please note the dating requirements. In a WAA, the Workplace Start Date, the day waste is first added to the container, is the same as the WAA receival or accumulation start date. Waste must be removed from your site within 60 days of this date under LBL policies. The accumulation start date for containers in SAAs is the date you seal the container and request transfer to the HWHF. This date must be no more than 275 days after the Workplace Start Date. For details on dating requirements, see the Guidelines for Satellite Accumulation Areas (SAAs)at LBL (PUB-3094) and Guidelines for Waste Accumulation Areas (WAAs) at LBL (PUB-3093).

Other labels, such as CARCINOGENIC WASTE, PCB WASTE, or FLAMMABLE LIQUID, must be attached to the package as appropriate. See the Hazardous Waste Disposal Requisition (Appendix A) or Chapter 5 (Chemical Safety) in PUB-3000, the LBL Health and Safety Manual, for details.

Waste containers will be picked up only if the label is filled out properly.

\section{Section 9: Transferring Your Waste to the HWHF}

When you have a waste container that is ready to be transferred to the HWHF, fill out a Hazardous Waste Disposal Requisition and fax it, along with any supporting documentation (described in detail in the Characterization section), to EH\&S at ext. 4838. This fax number is dedicated to the transmission of Hazardous Waste Disposal Requisitions. After EH\&S has received your faxed Hazardous Waste Disposal Requisition, EH\&S personnel will check your waste to make sure it meets the requirements listed in these guidelines. For waste organic solvents only, fill out the Waste Organic Solvents tag shown in Figure 4. If the waste does not meet the criteria, the EH\&S representative will tell you how to meet the criteria. 


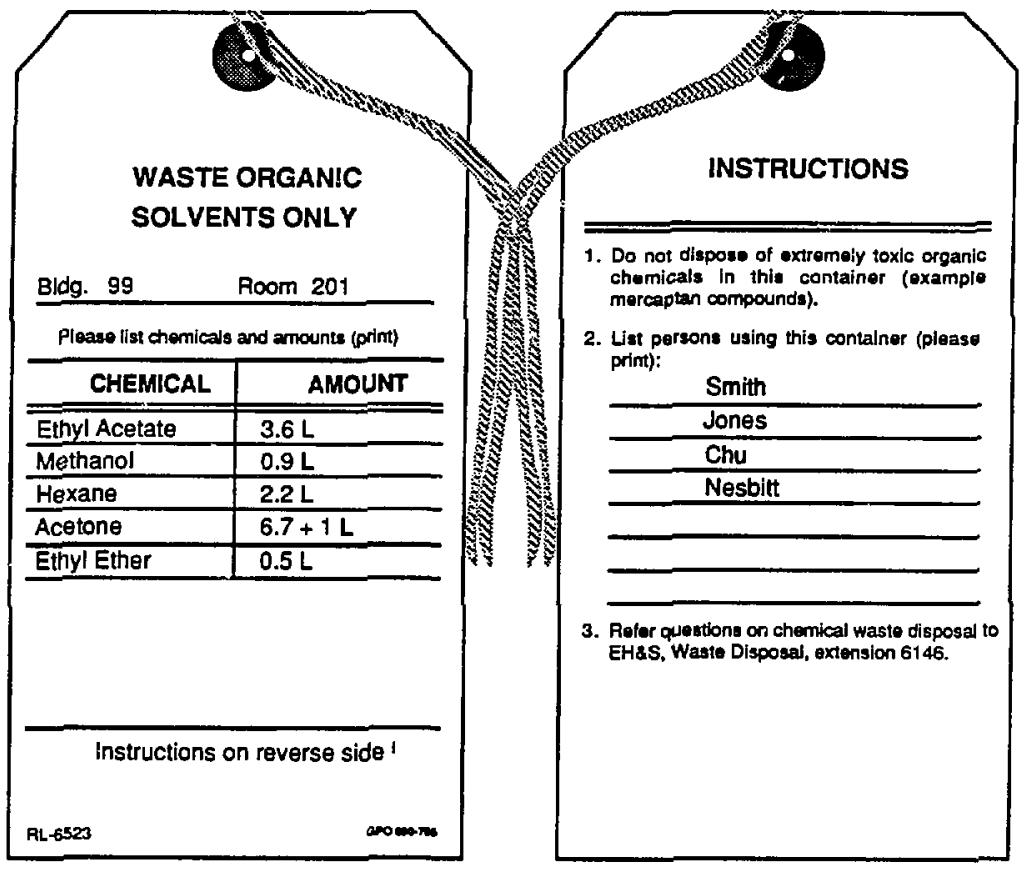

Figure 4. Waste Organic Solvents tag (front and back) 


\section{Section 10: Characterization}

\subsection{General}

Waste characterization must be taken seriously. Random samples of all wastes passing through the HWHF will be assayed to verify the accuracy of the information on the labels. The sampling frequency will vary depending on the type of waste, but the overall objective of the sampling is for the HWHF to sample the wastes with enough frequency to be sure that all wastes are characterized accurately enough to ensure

- safe handling,

- compliance with Federal and State packaging requirements,

- compliance with land disposal restrictions, and

- acceptance of the wastes by the relevant disposal or recycling facility.

Projects that consistently accumulate wastes with inaccurate labels could forfeit the use of the HWHF and therefore severely limit their research activities. Furthermore, discovery of inaccurately labeled waste by a regulatory agency could result in fines and criminal penalties for LBL staff and could jeopardize the operation of the HWHF.

All wastes must be characterized fully, as provided by the criteria below, before they can be accepted for shipment to the HWHF. This characterization is essential for LBL to ensure that your waste is handled and disposed of in a safe manner and by a process designed to enhance waste minimization and protect the environment.

You must first determine whether your waste is hazardous or not. If your waste is hazardous, it must be characterized by type of hazard, anis all the hazardous components must be fully identified. This requirement for characterization may be met in the following ways:

- process knowledge of wastes whose composition is documented by the procedures generating them, and records (logs) of accumulations that contain an entry each time a chemical is added to a container.

- an MSDS for all chemicals or materials used in an experiment or process;

- an MSDS for spent or unused'materials;

- a generic description when the material has a well-known standard composition (e.g., waste iatteries or waste mercury-contaminated glassware);

- analytic results from a certified laboratory on known waste streams where the chemical makeup will not change for some time (that is, a waste profile); or 
- analytic results from a certified laboratory for each sample (see Required Analyses for Waste Characterization below).

When you submit your Hazardous Waste Disposal Requisition, each entry on the requisition must be supported by documentation verifying its composition (i.e., process knowledge, MSDS, standard composition, a request for a profile analysis or profile analysis with an assigned number, or analytical results). The last column on the requisition form provides the information needed by the HWHF to process your request.

\subsection{Process Knowledge}

Because most chemical wasie is generated during specific processes in the course of your experiments, you should know the chemical contents of a unit of waste from your "knowledge of the process" used to generate that waste. This knowledge should include how the chemicals were used and whether the process produced hazardous chemicals where none existed before, or possibly even converted hazardous chemicals to harmless ones. Furthermore, you should be able to validate the contents on the basis of the pertinent written procedures, logs of your activities (see the Record of Waste Accumulation form, Figure 2), and the results of analyses conducted in the course of the experiment and recorded in your data books.

\subsection{Waste Profiling}

If you generate more than five gallons of liquid hazardous waste per month of a known waste stream whose composition and chemical makeup will not change over time, you may choose to have your waste evaluated (i.e., profiled) to avoid completing required analyses for every batch of waste. The parameters for which the waste should be analyzed, the rationale for their selection, and the sampling and analytical methods to be used during profiling are the same as those listed in LBL's Waste Analysis Plan for the general waste classifications handled by the HWHF. Submission of a Waste Profile Worksheet (see Appendix B) will alert the HWHF that you have wastes to be profiled or identified using this plan. HWHF personnel are available to assist you with sampling and with the arrangements for analysis of the waste to be profiled. A HWHF chemist will review the data; and, if the waste qualifies, the chemist will issue you a numbered profile for the waste stream. You then write this number on the Hazardous Waste Disposal Requisition for each subsequent shipment of the waste to the HWHF. You can simplify the waste disposal process greatly by qualifying your waste under a profile number. Appendix B provides details on profiling wastes. 


\subsection{Required Analyses for Waste Characterization}

If you cannot characterize your waste properly from the original label or from your documented knowledge of the processes used to generate a given hazardous waste, you must resort to specific analyses for waste characterization. To initiate this process, fill out and submit a Laboratory Waste Analysis Request Form (see Figure 5). The staff of the Environmental Protection Department can assist you in this process (see Section 12, Who to Call for Further Information), but the cost must be borne by the research project.

Below is a list of wastes, along with the information you will need to list on the Laboratory Waste Analysis Request Form, as well as the laboratory analyses that may be required for ea ih waste. Samples taken for chemical analysis will also be assayed for radioactivity as a quality assurance check. The HWHF may require additional analysis for disposal of a particular waste.

- Acids and Bases. List acid or base strength in appropriate units (normality, molarity, or percent by weight). A pH measurement is valid only if between 3 and 10. (Inorganic fluoride and chloride analyses are required for all mixed acid solutions for which no halide concentrations are given.) Identify all metals present and give their concentrations.

- Plating or Heavy Metal Solutions. List cyanide concentration if cyanide is present. (Cyanide analysis is required for all aqueous solutions, acid or base, generated in areas where cyanide is present.) Identify all metals present and give their concentrations.

- Nonchlorinated or Mixed Organic Solvents. List all constituents of the mixture. (Analysis for halogenated hydrocarbon concentrations may be required.) List flashpoint if known. (The flashpoint must be determined if the flammability of the solvent mixture is unknown.)

- Oils. List all constituents, and flashpoint if known. [Analyses for volatile halocarbon solvents, PCBs, percent oil, and flashpoint (if the oil has volatile components) may be needed.] All hydrocarbon-based oils must be analyzed. Silicone oils are not oils in the chemical or waste-definition sense and do not need to be analyzed. Label the silicone oils "silicone fluids" for disposal purposes.

- Coolants. List all constituents. [Analyses may be required for volatile halocarbon solvents, percent oil, and/or metal contaminants (beryllium, uranium, nickel, etc.), depending on use.] 
Two new features have been introduced in the design to permit measurement of high multiplicity events. One feature is the use of full pad coverage of the active volume to perform both $\mathrm{dE} / \mathrm{dx}$ measurements and tracking (previous designs have relied on the wire signals for the $\mathrm{dE} / \mathrm{dx}$ measurement). The second feature is placement of the eitire electronics on the detector, a new concept, that will find many applications in future big detectors. The mechanical design of the detector calls for the pad plane and electronics to be located directly below the drift volume. The pad plane is a single panel with an array of $8 \mathrm{~mm}$ wide by $12 \mathrm{~mm}$ long pads covering a $96 \mathrm{~cm}$ by $160 \mathrm{~cm}$ rectangle $(15,360$ pads total). The useable vertical drift distance is about $80 \mathrm{~cm}$. The electronics for the pads will be highly multiplexed thus greatly reducing the cabling requirements ( 128 optical fibers for data transmission). The expected event rate limit for the electronics will vary from 10 to 100 events per one second beam spill, depending on particle multiplicity of the event. A summary of the TPC specifications are listed in the following table.

\begin{tabular}{|l|l|}
\hline \multicolumn{2}{|c|}{ HISS TPC Characteristics } \\
\hline Pad Plane Area: & $1.5 \mathrm{~m} \times 1.0 \mathrm{~m}$ \\
\hline Number of Pads: & 15360 (full coverage) \\
\hline Pad Size: & $12 \mathrm{~mm} \times \mathbf{m m}$ \\
\hline Drift Distance: & $75 \mathrm{~cm}$ \\
\hline Time Sampling Frequency: & $10 \mathrm{MHz}$ \\
\hline Pad Amplifier Shaping Time: & $250 \mathrm{~ns}$ \\
\hline Electronics Noise: & $700 \mathrm{e} \mathrm{rms}$ \\
\hline Gas Gain: & 3000 \\
\hline Gas: & $90 \% \mathrm{Ar}+10 \% \mathrm{CH}$ \\
\hline Gas Pressure: & 1 atmosphere \\
\hline B field: & $13 \mathrm{KG}$ \\
\hline & \\
\hline Event Rate: & $10-80$ events/ $1 \mathrm{sec} \mathrm{spill}$ \\
\hline dE/dx(particle range): & $\mathrm{Z}=1-8$ \\
\hline & $0, \pi \pm, \mathrm{p}, \mathrm{d}, \mathrm{l},{ }^{3} \mathrm{He},{ }^{4} \mathrm{He}, \mathrm{Li}-\mathrm{O}$ \\
\hline Two Track Resolution: & $2.5 \mathrm{~cm}$ \\
\hline Solid Angle Coverage: & $2 \pi \mathrm{Lab}$. \\
\hline Multiplicity Capability & 200 \\
\hline
\end{tabular}


- Solid Wastes and Sludges. Solid wastes and dried sludges destined for a Resource Conservation and Recovery Act (RCRA) landfill will require a toxic characteristic test (TCLP). This test requires analysis for the following metals in the extract: arsenic (As), barium (Ba), cadmium (Cd), chromium $(\mathrm{Cr})$, mercury $(\mathrm{Hg})$, lead $(\mathrm{Pb})$, vanadium $(\mathrm{V})$, selenium $(\mathrm{Se})$, silver $(\mathrm{Ag})$, copper $(\mathrm{Cu})$, nickel $(\mathrm{Ni})$, zine $(\mathrm{Zn})$, thallium ( $\mathrm{Tl})$, and cobalt $(\mathrm{Co})$.

- Unknowns. Before the waste can be shipped to the HWHF, all hazardous components must be identified by the generator, and all unknowns must be analyzed by a certified laboratory. A copy of the laboratory report must accompany the Hazardous Waste Disposal Requisition when it is faxed to EH\&S. For assistance, contact EH\&\&, ext. 5251.

For information on necessary analyses, contact EH\&S, ext. 5251. 
Approved By:

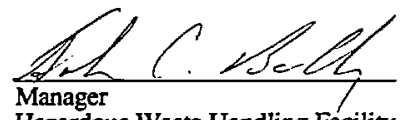

Date: $7 / 17 / 91$

Hazardous Waste Handling Facility

Hazardous Waste Management Department

Environment, Health and Safety Division

Approved By:
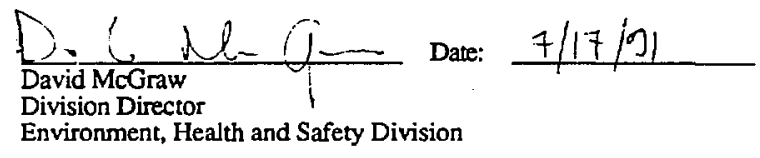

Approved By:

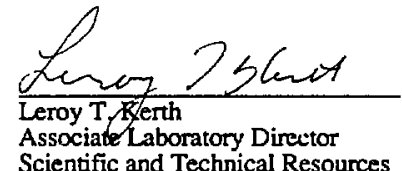

Date: $7 / 17 / 91$

Scientific and Technical Resources 


\section{Guidelines for Generators of Radioactive and Mixed Waste at LBL}




\section{Contents}

Guidelines for Generators of Radioactive and Mixed Waste at LBL

1. Introduction

RAD-1

2. Governing Documents

RAD-2

3. Definitions

RAD-4

4. Characterization

RAD-6

5. Requirements Applying to All Radioactive and Mixed Wastes RAD-12

6. Requirements Unique to Each Waste Stream

RAD-17

List of Figures

Figure 1. Flowchart for hazardous waste at LBL RAD-3

Figure 2. Record of Waste Accumulation form RAD-9

Figure 3. Laboratory Waste Analysis Request Form

RAD-11

Figure 4. Radioactive Waste tag (front side only)

RAD-15 


\section{Guidelines for Generators of Radioactive and Mixed Waste at LBL}

\section{Section 1: Introduction}

The purpose of this document is to provide the acceptance criteria for the transfer of radioactive and mixed waste to LBL's Hazardous Waste Handling Facility (HWHF). These guidelines describe how you, as a generator of radioactive or mixed waste, can meet LBL's acceptance criteria for radioactive and mixed waste.

Much of the research at LBL involves radioactive materials. This research results in both radioactive waste and radioactive waste mixed with hazardous chemicals (called "mixed waste"). Proper handling of this radioactive and mixed waste is important if LBL is to maintain a safe and healthful environment.

All radioactive and mixed waste generated by $L B L$ research activities is transferred to the HWHF. The HWHF is managed by the Environment, Health and Safety Division. The waste is treated, if necessary, and packaged for shipment to the Hanford Waste Disposal Site in Richland, Washington. The Westinghouse Hanford Company, which runs the Hanford Site, establishes the criteria (in conjunction with DOE) for acceptance of these wastes. These criteria are described in the Hanford Radioactive Solid Waste Packaging, Storage, and Disposal Requirements, WHC-EP-0063-2, the disposal/storage manual of the Westinghouse Hanford Company. All the requirements listed in this document respond to the requirements of the Hanford Disposal site.

Further information on handling of all kinds of radioactive and mixed waste is listed in Chapter 21 (Radiation Safety) of PUB-3000, the LBL Health and Safety Manual.

If you generate radioactive or mixed waste, the requirements listed in PUB-3000 and this document apply to you. You must follow these requirements if you want your waste to be transported to the HWHF. EH\&S personnel will check your waste to make sure it meets the acceptance criteria listed in these guidelines. If the waste does not meet the criteria, the EH\&S representative will provide advice on how to meet the criteria.

Following this introduction, these guidelines are divided into five sections:

- Governing Documents

- Definitions

- Characterization

- Requirements Applying to All Radioactive and Mixed Wastes

- Requirements Unique to Each Waste Stream 
The Definitions section provides guidelines on defining different kinds of waste, as well as providing definitions of other terms that you should know. The Characterization section should help you determine what kind of waste you have. The Requirements Applying to All Radioactive and Mixed Wastes section provides the guidelines you need to help you separate, package, and label your waste so that it meets the acceptance standards necessary for your waste to be transferred to the HWHF. Information is also provided on good housekeeping and minimization of radioactive and mixed wastes. The Requirements Unique to Each Waste Stream section lists separation, packaging, and labeling details that are unique to each waste stream.

Figure 1 shows the flowchart for hazardous waste at LBL.

\section{Section 2: Governing Documents}

The following documents apply to the handling of radioactive and mixed wastes at LBL:

- United States Environmental Protection Agency, 40 Code of Federal Regulations (40 CFR)

- United States Department of Transportation, 49 Code of Federal Regulations (49 CFR)

- Occupational Safety and Health Administration, 29 Code of Federal Regulations (29 CFR)

- United States Department of Energy Orders 5280.2A, 5400.3

- California Code of Regulations (CCR) Title 22

- California Department of Health Services Hazardous Waste Control Law (excerpt from Health and Safety Code, Division 20)

- EPA SW-846 (an EPA manual for solid waste analysis)

- PUB-3000, the LBL Health and Safety Manual

- LBL's Waste Analysis Plan, Pub-5309 (May 5, 1991 issue)

- Hanford Radiactioe Solid Waste Packaging, Storage, and Disposal Requirements, WHC-EP-0063-2

- Transuranic Waste Acceptance Criteria for the WIPP, WIPP-DOE-069 


\section{Generator's Guide to Hazardous Waste Disposal at LBL}

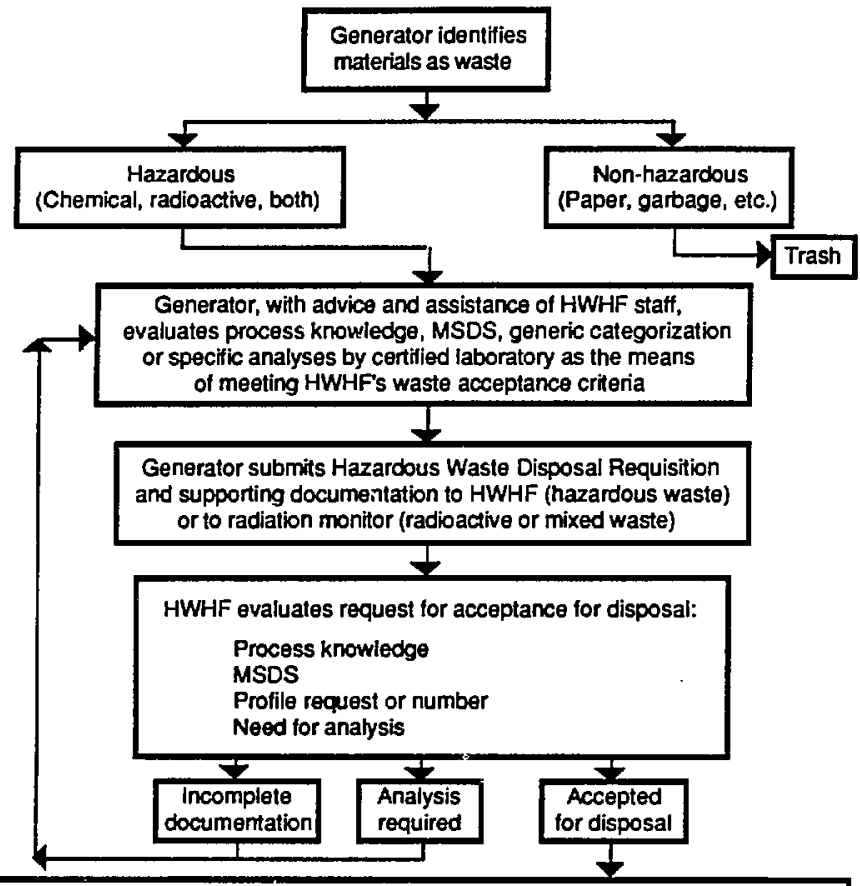

OAOC: Random sample analysis to verify generator's chemical characterization

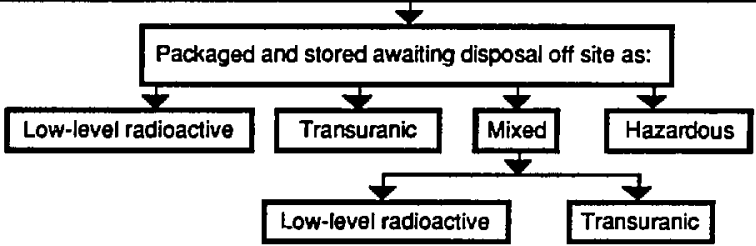

Figure 1. Flowchart for hazardous waste at LBL. 


\section{Section 3: Definitions}

Low-level waste is waste containing radioactivity that is not classified as highlevel waste, transuranic waste (waste from elements 93 and higher), spent nuclear fuel, or byproduct material, as defined in DOE Orders 5280.2A and 5400.3. At $L B L$, low-level waste is divided into the following categories for the purpose of safe handling:

- Low-specific-activity (LSA) alpha waste, solid. LSA solid alpha waste must have radioactivity levels below $100 \mathrm{nCi} / \mathrm{g}$. Low-level solid waste with activity levels above $100 \mathrm{nCi} / \mathrm{g}$ must be kept separate from LSA waste.

- Low-level alpha waste, liquid. Low-level liquid alpha waste must have radioactivity levels below $100 \mathrm{nCi} / \mathrm{ml}$.

- Low-level beta and gamma waste, solid. Low-level solid beta and gamma solid waste must have radioactivity levels below $0.3 \mathrm{mCi} / \mathrm{g}$. The exception is $90 \mathrm{Sr}$, for which the beta and gamma levels must be below $0.005 \mathrm{mCi} / \mathrm{g}$. Nonradioactive material contaminated with radioactivity less than $0.001 \mathrm{mCi} / \mathrm{cm}^{2}$ (measured on the surface) is considered to be low-level beta or gamma solid waste.

- Low-level beta and gamma waste, liquid. Low-level liquid beta and gamma waste must have radioactivity levels below $0.3 \mathrm{mCi} / \mathrm{ml}$. The exception is $90 \mathrm{Sr}$, for which the beta and gamma levels must not exceed $5 \mu \mathrm{Ci} / \mathrm{ml}$.

Transuranic (TRU) waste is waste, without regard to source or form, that is contaminated with alpha-emitting transuranium radionuclides (elements 93 and higher) with half-lives greater than 20 years and concentrations greater than 100 $\mathrm{nCi} / \mathrm{g}$ at the time of assay. Radium sources and $\mathrm{U}-233$ are also considered to be TRU waste. Radioactive waste with quantities of transuranic radionuclides in concentrations of $100 \mathrm{nCi} / \mathrm{g}$ of waste or less is considered to be low-level waste and not TRU waste. Transuranic waste generated at LBL will eventually be shipped to the Hanford Site and placed in interim storage pending eventual shipment to the Waste Isolation Pilot Project (WIPP) in New Mexico. All transuranic waste must met the criteria of WIPP-DOE-069, Transuranic Waste Acceptance Criteria for the WIPP. These criteria are incorporated into this document.

High-level waste is the highly radioactive waste material that results from the reprocessing of spent nuclear fuel, including liquid waste produced directly in 
reprocessing and any solid waste derived from the liquid, that contains a combination of transuranic waste and fission products in concentrations requiring permanent isolation.

\section{Hazardous wastes are}

- wastes listed in the California Code of Regulations (22 CCR 66680) and the Code of Federal Regulations (40 CFR Part 261)

- wastes that exhibit one or more of the criteria for identification of "hazardous waste" (22 CCR 66693-66723). These criteria are

- toxicity

- persistent and bioaccumulative effect

- ignitibility

- reactivity

- corrosivity

- radioactive mixed wastes (materials that contain both hazardous chemical and radioactive wastes)

- wastewater that exceeds sanitary-sewer discharge limits.

Extremely hazardous substances are any of $\mathbf{4 0 6}$ chemicals identified by EPA on the basis of toxicity and listed under SARA Title III.

Ignitable wastes include liquids with a flash point of less than $140^{\circ} \mathrm{F}$, solids that ignite spontaneously through absorption of moisture or through friction and burn vigorously, flammable gases, and oxidizers.

Radioactive mixed waste is any radioactive waste that also includes substances defined as hazardous by the Resource Conservation and Recovery Act. The current trend in waste management is to define more, rather than fewer, substances as hazardous. Thus, radioactive mixed waste can be expected to represent a larger percentage of LBL's waste streams over time.

Material with any level of radioactivity above the natural background level, when mixed with hazardous waste, constitutes radioactive mixed waste. The combination of radioactivity and hazardous chemicals makes this waste particularly expensive and difficult to handle, transport, and store. Currently, radioactive mixed waste cannot be disposed. Therefore, it is imperative to minimize or avoid it whenever possible. In particular, avoid mixing separate chemical and radioactive wastes, thus creating radioactive mixed waste wivere none existed before. Avoidance of radioactive mixed waste may require developing new techniques, procedures, and/or experimental approaches.

A controlled area (for radiation protection) is an area where radioactive materials or elevated radiation fields may be present. 
Certification means that the person who signs his or her name on the Radioactive Waste Tag (attached to each package of radioactive waste to be sent to the HWHF; see Figure 4 on page 15) says (or certifies) that the contents of the radioactive waste package are described exactly and correctly by the tag. This description (and the signature) are legally binding.

Knowledge of process (also known as user knowledge) refers to the ability of the generator to characterize waste on the basis of knowing the processes by which the waste vas generated. It also includes being able to verify the characterization with the documented procedures used and data accumulated during the wastegeneration process. Either chemical analysis or user knowledge (or a combination of both) is required for generator certification of the hazardous waste and must be part of the waste description.

A waste generator is the individual or operation responsible for actually generating the hazardous waste within an organization. LBL as a whole is viewed as a waste generator by environmental regulatory agencies. Within LBL, each researcher, laboratory, shop, and facility, as a potential point of origin for hazardous waste, is a waste generator.

A waste-generating organization is the program, facility, or group that generates the waste.

A waste stream is waste generated from an industrial process or application, laboratory experiment, or routine laboratory procedure, with roughly constant and unchanging hazardous and/or radioactivity characteristics.

Segregate in this document means "do not mix" chemically unrelated or incompatible materials in the same container.

Separate means "set apart" in this document.

Treatment means any method, technique, or process designed to change the physical, chemical, or biological character or composition of any hazardous waste. (This definition is taken from 40 CFR 260.10 and 22 CCR 66216.) Neutralization and dilution are examples of processes that are considered treatments by Federal and state regulations.

\section{Section 4: Characterization}

Waste characterization must be taken seriously. Random samples of all wastes passing through the HWHF will be assayed to verify the accuracy of the information on the labels. The sampling frequency will vary depending on the kind of the waste, but the overall objective of the sampling is for the HWHF to 
sample the wastes with enough frequency to be sure that all wastes are characterized accurately enough to ensure

- safe handling

- compliance with EPA (and State of Washington) packaging requirements

- compliance with land disposal restrictions, and

- acceptance of the wastes by the relevant disposal facility.

Projects that consistently accumulate wastes with inaccurate labels could forfeit the use of the HWHF and therefore severely limit their research activities. Furthermore, discovery of inaccurately labeled waste by a regulatory agency could result in fines and criminal penalties for LBL staff and could jeopardize the operation of the HWHF.

The Hanford Waste Site requires that radioactive and mixed waste be characterized in great detail. It is your responsibility as generator of the waste to provide sufficient detail to fully characterize your waste both chemically and radiologically. The definitions listed in these guidelines are designed to help you characterize your waste to meet the standards established by the Hanford Site, as well as shipping standards established by the U.S. Department of Transportation. The detailed requirements for both radioactive and chemical characterization are listed below.

\subsection{Radioactive Characterization}

Radioactive content should be assayed, or known from previous assays during processing (knowledge of process). You may determine the concentration of a radionuclide either by direct methods, or by indirect methods such as radionuclide material accountability or the use of scaling factors that relate the inferred concentration of one radionuclide to another that is measured, if there is reasonable assurance that the indirect methods can be correlated with actual measurements. Provide the method of assay or analysis used to determine radionuclide distribution and concentration, and be able to document these assays, if necessary. For solid waste, make the best possible estimate of radioactive content. User knowledge is appropriate when it can be documented (e.g., logs or chemical balance sheets, published information, process tank formulas/recipes, manufacturer product information, MSDSs, process production information).

Radioactive characterization must also include reporting any parent-daughter pairs. For example, ${ }^{137} \mathrm{Ba}$ must be reported with ${ }^{137} \mathrm{Cs}$, and $90 \mathrm{Y}$ must be reported with ${ }^{90} \mathrm{Sr}$. 
Naturally occurring radioisotopes should be disposed of as radioactive waste if they are the reason for the waste's being declared radioactive, or if they have been enriched in any way. If the isotopes are incidental to fission or activation products that cause the waste to be declared radioactive, then the naturally occurring radioisotopes need not be listed on the Radioactive Waste tag.

\subsection{Chemical Characterization}

Although you may think that your radioactive waste is not mixed with hazardous chemicals (and therefore is not mixed waste), the current trend in waste management is to define more, rather than fewer, substances as hazardous. Therefore, you should consider that all of your radioactive waste is potentially mixed waste. Thus, chemical characterization of your radioactive waste should be as rigorous as hazardous chemical waste characterization, even if you think that your waste is not mixed waste.

You must first determine whether the chemical portion of your waste is hazardous or not. If it is hazardous, it must be characterized by type of hazard, and all the hazardous components must be fully identified. This requirement for characterization may be met in the following ways:

- process knowledge of wastes whose composition is documented by the procedures generating them, and records (logs) of accumulations that contain an entry each time a chemical is added to a container;

- an MSDS for spent or unused materiais;

- a generic description when the material has a well-known standard composition (e.g., waste batteries or waste mercury-contaminated glasswcre);

- analytic results from a certified laboratory on known waste streazns where the chemical makeup will not change for some time (that is, a waste profile); or

- analytic results from a certified laboratory for each sample (see Section 4.2.3, Required Analyses for Waste Characterization, below).

\subsubsection{Process Knowledge}

Because most chemical waste is generated during specific processes in the course of your exper nents, you should know the chemical contents of a unit of waste from your "knowledge of the process" used to generate that waste. This knowledge should include how the chemicals were used and whether the process produced hazardous chemicals where none existed before, or possibly even converted hazardous chemicals to harmless ones. Furthermore, you should be able to validate the contents on the basis of the pertinent written procedures, logs of your activities (see Figure 2, the Record of Waste 


\section{LAWRENCE BERKELEY LABORATORY RECORD OF WASTE ACCUMULATION}

\begin{tabular}{|c|c|c|c|}
\hline ADATE & DESCRIPTIONOFWHAT WASADDED & AMOUNT & INTTLALS \\
\hline $6 / 7 / 91$ & Ethyl Acetate & $500 \mathrm{ML}$ & SBS \\
\hline 67 & Mothanol & $.5 \mathrm{~L}$ & wo \\
\hline $6 / 8$ & Hexane & $1.0 \mathrm{~L}$ & RAJ \\
\hline $6 / 10$ & Acetone & $1.0 \mathrm{~L}$ & wo \\
\hline $6 / 15$ & Acotono & $.2 \mathrm{~L}$ & SBS \\
\hline $6 / 15$ & Ethyl Acotate & $.1 \mathrm{~L}$ & KaN \\
\hline$-6: 46$ & Acotonom- & $-400+11$ & RAL \\
\hline $6 / 20$ & Mothanol & $.2 \mathrm{~L}$ & mo \\
\hline $6 / 21$ & Acotono & $2.0 \mathrm{~L}$ & wc \\
\hline $6 / 23$ & Ethyl Acotate & $2.0 \mathrm{~L}$ & wc \\
\hline $6 / 23$ & Hexane & $1.2 \mathrm{~L}$ & KMN \\
\hline $7 / 4$ & Acotone & $.5 \mathrm{~L}$ & SBS \\
\hline $7 / 1$ & Acotone & $1000 \mathrm{ML}$ & we \\
\hline $7 / 2$ & Ethyl Acotate & $1.0 \mathrm{~L}$ & SBS \\
\hline $7 / 2$ & Acetone & $3.0 \mathrm{~L}$ & RAS \\
\hline $7 / 3$ & Bank Mothand & $0.2 \mathrm{~L}$ & KMN \\
\hline & 716 & & \\
\hline & & & \\
\hline & & & \\
\hline & & & \\
\hline & & & \\
\hline & & & \\
\hline & & & \\
\hline & & & \\
\hline
\end{tabular}

Figure 2. Record of Waste Accumulation form. See Appendix D for a full-sized form. 
Accumulation form), and the results of analyses conducted in the course of the experiment and recorded in your data books.

\subsubsection{Waste Profiling (for Mixed Waste Only)}

If you generate more than five gallons of liquid hazardous waste per month of a known waste stream whose composition and chemical makeup will not change

over time, you may choose to have your waste evaluated (i.e., profiled) to avoid completing required analyses for every batch of waste. The parameters for which the waste should be analyzed, the rationale for their selection, and the sampling and analytical methods to be used during profiling are the same as those listed in LBL's Waste Analysis Plan for the general waste classifications handled by the HWHF. Submission of a Waste Profile Worksheet (see Appendix B) will alert the HWHF that you have wastes to be profiled or identified using this plan. HWHF personnel are available to assist you with sampling and with the arrangements for analysis of the waste to be profiled. A HWHF chemist will review the data; and, if the waste qualifies, the chemist will issue you a numbered profile for the waste stream. You then write this number on the Hazardous Waste Disposal Requisition (see Appendix A) for each subsequent shipment of the waste to the HWHF. You can simplify the waste disposal process greatly by qualifying your waste under a profile number. Appendix B provides details on profiling wastes.

\subsubsection{Required Analyses for Waste Characterization}

If you cannot characterize your waste properly from the original label or from your documented knowledge of the processes used to generate a given hazardous waste, you must resort to specific analyses for waste characterization. To initiate this process, fill out and submit a Laboratory Waste Aralysis Request Form (see Figure 3). The staff of the Environmental Protection Department can assist you in this process (see Appendix C, Who to Call for Further Information), but the cost must be borne by the research project.

Below is a list of wastes, along with the information you will need to list on the Laboratory Waste Analysis Request Form, as well as the laboratory analyses that may be required for each waste. The HWHF may require additional analysis for disposal of a particular waste.

- Acids and Bases. List acid or base strength in appropriate units (normality, molarity, or percent by weight). A pH measurement is valid only if between 3 and 10. (Inorganic fluoride and chloride analyses are required for all mixed acid solutions for which no halide concentrations are given.) Identify all metals present and give their concentrations. 


\section{世}

LAWRENCE BERKELEY LABORATORY

LABORATORY WASTE ANALYSIS REQUEST FORM

\section{Far ELSHC areaby}

Sample Taken By:

Mahod of Sampling:

GENERATORASUBMOTTER WFORYATION

NAXE: M. Sutton PAYROLL ACCT: 9078

SAMPLER INFORMATHON

LOCATION (BIdG. RONO): 75 CONTACT PERSON: M. SUtton

Type of Conuiner 55 gal drum

SUSPECTED CHEMICAL COATOSTION \& DESCRIDUONOF PROCESS OR EXPERIMENT ORLGIN IN DETAIL (E.G., PHOTOCRAPHLC, ETCHING, HUMAN GENOME, CHROMUTOGRAPHY, ETC)

Machining and grinding sludge collected over 2 months. Has polish, ail, lapping oil and some aluminum oxide w/resin. Estimate $70 \%$ water. May contain hoavy metals liko nickol.

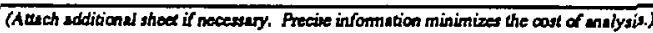

\section{INDICATETHE SUPEORTUNG DOCUMENT THAT IS ATUACHED:}

Y MSDS for tach continuent

a Formulntion(s)

9 Chemical compdrition

8. Record of how the watle was accunulned in the conlsiner (bate, what was added, the anount and initials for ench addition)

a Oher

\section{THESAMPLEIS POTENTALLY:}
- artinozenic
a corrosive
D explonive
D flanmable
Q an oxidizer
poisonous
D ndionctive
reaclive

\section{RADLOACTIVE INEOBMATION}

Radionuclide(s): N/A. Not a "controlled area",

Acivity:

Mechods of Alsy:

Performed by:

(HHHF GSAI RCRM)

Figure 3. Laboratory Waste Analysis Request Form. See Appendix D for a full-sized form. 
- Plating or Heavy Metal Solutions. List cyanide concentration if cyanide is present. (Cyanide analysis is required for all aqueous solutions, acid or base, generated in areas where cyanide is present.) Identify all metals present and give their concentrations.

- Nonchlorinated or Mixed Organic Solvents. List all constituents of the mixture. (Analysis for halogenated hydrocarbon concentrations may be

required.) List flashpoint if known. (The flashpoint must be determined if the flammability of the solvent mixture is unknown.)

- Oils. List all constituents, and flashpoint if known. [Analyses for volatile halocarbon solvents, PCBs, percent oil, and flashpoint (if the oil has volatile components) may be needed.]. All hydrocarbon-based oils must be analyzed. Silicone oils are not oils in the chemical or waste-definition sense and are excepted. Label the silicone oils "silicone fluids" for disposal purposes.

- Coolants. List all constituents. [Analyses may be required for volatile halocarbon solvents, percent oil, and/or metal contaminants (beryllium, uranium, nickel, etc.), depending on use.]

- Solid Wastes and Sludges. Solid wastes and dried sludges destined for a Resource Conservation and Recovery Act (RCRA) landfill will require a toxic characteristic test (TCLP). This test requires analysis for the following metals in the extract: arsenic (As), barium (Ba), cadmium (Cd), chromium $(\mathrm{Cr})$, mercury $(\mathrm{Hg})$, lead $(\mathrm{Pb})$, vanadium (V), selenium (Se), silver (Ag), copper $(\mathrm{Cu})$, nickel $(\mathrm{Ni})$, zinc $(\mathrm{Zn})$, thallium $(\mathrm{Tl})$, and cobalt $(\mathrm{Co})$.

- Unknowns. All unknowns must be analyzed by a certified laboratory and their hazardous components identified by the generators before the waste can be shipped to the HWHF. A copy of the laboratory report must accompany the Hazardous Waste Disposal Requisition when it is faxed to EH\&S. For assistance, contact EH\&S, ext. 5251.

For information on necessary analyses, contact EH\&S, ext. 5251.

\section{Section 5: Requirements Applying to All Radioactive and Mixed Wastes}

These requirements are designed to help you maintain a safe work environment and control your radioactive and mixed wastes. They apply to the handling of all radioactive and mixed wastes. They are divided into several categories: general housekeeping, minimization, characterization, separation, labeling, and packaging. (Note: whenever "radioactive waste" appears, it refers to both radioactive and mixed waste.) 


\subsection{General Housekeeping}

- Keep the buildup of radioactive wastes to a minimum.

- Be scrupulous about good housekeeping in hoods, glove boxes, and laboratories.

- Do not pour liquid radioactive waste down the saritary drain. If this should happen accidentally, call EH\&S, ext. 5251, immediately.

- Store gaseous, vaporous, and emanating waste in ventilated enclosures, or else have these wastes removed to the HWHF immediately.

- Waste having a radiation field that could cause personnel exposures must be removed to the HWHF immediately.

\subsection{Minimization}

- Minimize the gross volume of radioactive wastes by such practices as ordering only the amount of radioactive materials and chemicals used and designing your experiments to use the minimum amount of radioactive materials and chemicals needed.

- Try to modify your procedures to substitute nonhazardous substance's for hazardous substances.

- Recycle or reuse chemicals.

\subsection{Characterization}

- Analyze all radioactive materials before and after each chemical or physical operation, in order to separate them properly. See Section 3, Definitions, and Section 4, Characterization, in these guidelines for details of waste characterization.

- Do not add radioactive materials to any unknown (uncharacterized) mixtures.

\subsection{Separation and Segregation}

- Store radioactive wastes separately from hazardous waste (oxidizers, explosives, flammables, poisons, toxics, and corrosives).

- Separate radioactive and mixed wastes with half-lives of 45 days or shorter from other radioactive wastes. This is also a minimization step.

- Separate radioactive wastes into low-level waste, mixed hazardous and low-level wastes, transuranic wastes, and mixed hazardous and transuranic wastes. Keep each kind of waste in a separate container. 
- Do not add radioactive waste to hazardous wastes. This segregation step helps minimize mixed wastes, which are the most expensive and difficult wastes to dispose.

\subsection{Packaging}

- Place all radioactive sharp objects (hypodermic needles, spitzers, scalpels, etc.) in protective containers. Ice cream cartons [available from Stores in pint (item 8115-27762), quart (item 8115-27763), and two-quart (item 8115-27764)sizes] lined with plastic bags are acceptable. Do not place radioactive sharps in medical/biohazardous sharps containers.

- Do not overfill any radioactive or mixed waste container, liquid or dry.

- Make sure that the container is compatible with the contents (for example, no hydrofluoric acid in glass containers).

- Store all radioactive and mixed liquids in leak-tight containers inside secondary containments. Taping the bottle and placing the bottle inside a plastic bag meets this requirement.

- You must provide your primary waste containers (ice cream cartons, polyethylene bags, etc.). HWHF personnel provide approved waste collection containers (galvanized waste cans, 5-gallon carboys, etc.).

\subsection{Labeling}

- Attach a Radioactive Waste tag (Figure 4) to each radioacrive and mixed waste container. When you start a new waste container, attach the tag to the container and fill in the following information (the numbers are correlated with the numbers in Figure 4):

(1) Waste category (low-level, TRU, low-level mixed, TRU mixed, or induced metals)-check one category only

(2) Physical form (dry, aqueous liquid, organic liquid, gas, scintillation vials, biological)-check one category only

(3) Building, Room, Division, and Operator account number

(4) Your name (PRINTED)

- ivery time you add waste to the container, fill in all of the following that apply:

(5) Radioactivity (date placed in container, isotope, and quantity)

(6) Complete comporition, concentration, and weight in grams of all chemicals

(7) Dry waste constituents (item and volume percent) 


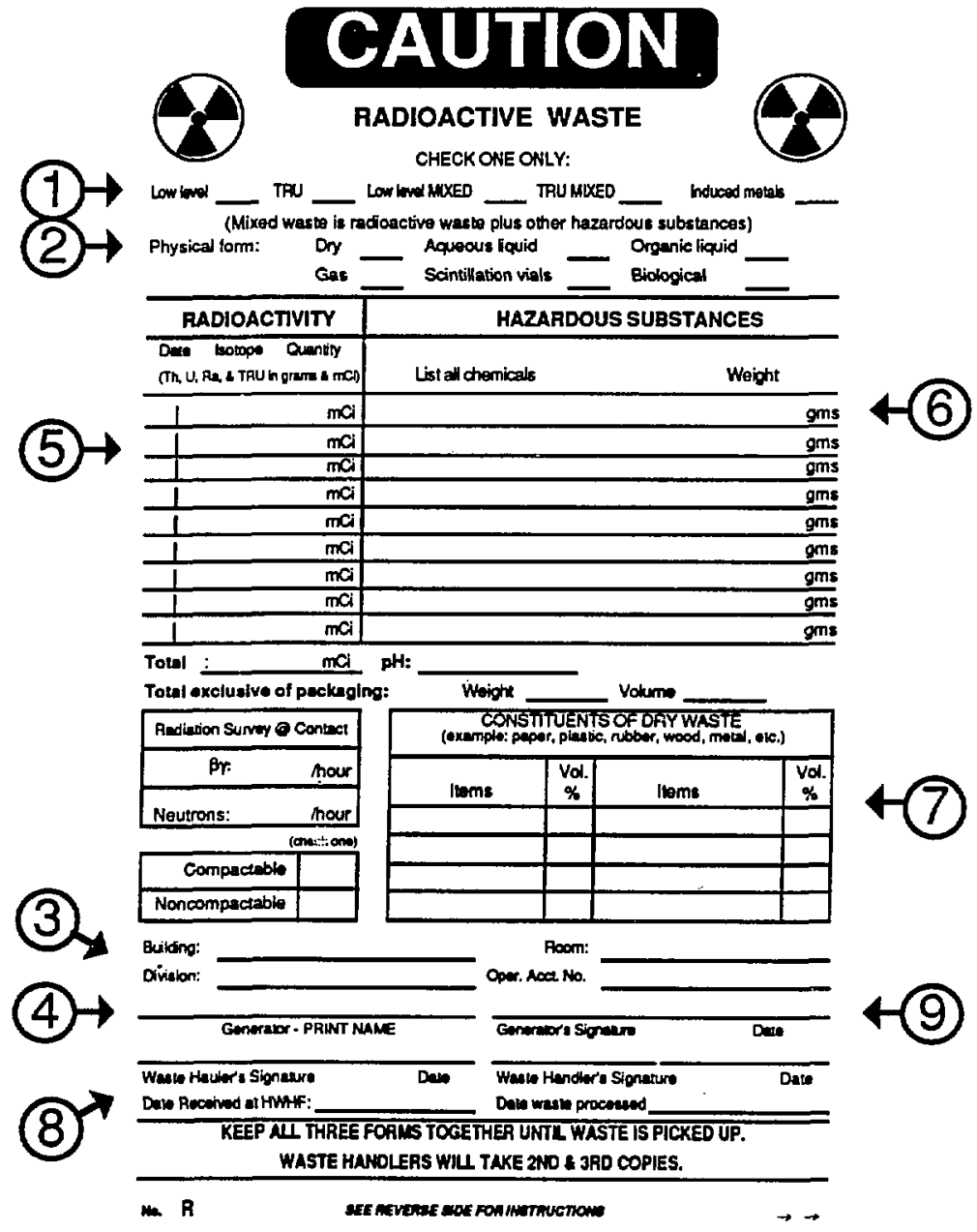

Figure 4. Radioactive Waste tag (front side only) 
- You must add to the waste tag every time you add waste to the container. As an alternative, the information for items (5) through (7) may be kept in a separate log; but a copy of this log must accompany the waste when it is transfered to the HWHF, and each entry must be linked to the entries on the Radioactive Waste tag. This alternative may be particularly attractive to research groups who regularly use complex chemical mixtures containing radioactivity. Call the Environmental Specialist, $x$ 5251, for further information about this alternative.

- Use a second tag if the space on the first tag is filled up.

- For radioactive (not mixed) waste, as soon as any waste container is filled, call EH\&S to arrange for pickup of the waste. EH\&S personnel will review the tag with you and check the waste container. If the EH\&S representative is satisfied that the tag is filled out correctly, he/she will sign the tag (8) in your presence. You will sign and date the tag (9) in the presence of the EH\&S representative at this time. Your signature on the waste tag means that you certify the accuracy of the inforrmation on the tag.

- Mixed waste must be identified with a Hazardous Waste label (see Figure 3 in the Guidelines for Generators of Hazardous Waste at $L B L$ ), as well as with a Radioactive Waste tag. An LBL Hazardous Waste Disposal Requisition (see Appendix A) and the supporting documentation (described in the Chemical Characterization section above) for chemical characterization must be filled out for mixed waste.

- If the tag and forms are filled out properly, the EH\&S representative will pick up your waste for transfer to the HWHF or will notify you of a pickup time.

Your waste will not be picked up if the tag and forms are not filled out correctly. 


\section{Section 6. Requirements Unique to Each Waste Stream}

Before radioactive and mixed wastes can be packaged at the HWHF, they must be separated into the proper waste streams. Basic separation and packaging procedures that apply to all radioactive and mixed wastes are listed in the Requirements Applying to All Radioactive and Mixed Wastes section above. This section describes requirements unique to each waste stream.

\subsection{Solid compacted dry waste}

- Keep these wastes inside a cement sack inside a $24^{\prime \prime} \times 38^{\prime \prime}$ polyethylene bag, all placed inside a 15-gallon waste can. [EH\&S provides the 15-gallon can. Cement sacks are available from Stores (item 810527692), as are poly bags (item 8105-51456).]

- Seal the plastic bag with 2-inch masking tape (Stores item 7510-12348).

- Tie and tape your filled-out Radioactive Waste tag (Figure 4) to the neck of the sealed plastic waste bag.

- NOTE: The maximum amount of alpha waste allowed in one 15gallon waste can is $50 \mu \mathrm{Ci}$.

6.2 Solid noncompacted dry waste (waste items greater than $4^{\prime \prime} \times 4^{\prime \prime} \times 4^{\prime \prime}$ )

- Keep these wastes inside a cement sack inside a 24 " $\times$ 36" polyethylene bag.

- Seal the plastic bag with 2-inch masking tape.

- Tie and tape your filled-out Radioactive Waste tag to the neck of the sealed plastic waste bag.

- Wrap large items (items that do not fit inside the bag) in plastic if containment is required. Each item requires its own filled-out Radioactive Waste tag.

\subsection{Induced metals}

Strap large pieces to pallets. Place small pieces in DOT-approved drums or wooden boxes. Label the large pieces (and the drums and boxes) with RADIOACTIVE stickers (provided by EH\&S).

\subsection{Animal carcasses and tissues}

Keep carcasses and tissues frozen, contained in plastic bags. Fill out a Radioactive Waste tag for each bag. 


\subsection{Scintillation vials}

Pack scintillation vials in 10-gallon plastic containers (provided by EH\&S). There should be no metal, absorbant, or other waste in the container. Scintillation fluid free of xylene or toluene can be sent to the Quadrex Corporation in Florida for incineration as fuel for an electrical power plant if the average radioactive content is below $50 \mathrm{nCi} / \mathrm{ml}$ per batch. This process is an example of waste minimization and recycling. Its success requires the cooperation of researchers to keep the radioactivity level in the scintillation fluid derived from research vials below the acceptable limit.

\subsection{Liquid waste (solidified at the HWHF)}

- Set up separate containers for acids, caustics, organic solvents, halogenated solvents, and aqueous solutions.

- Keep the liquid waste in plastic containers (liter size or 5-gallon carboys) whenever possible.

- Make sure that the container is compatible with the material contained in it (e.g., no hydrofluoric acid in glass bottles).

- Seal all containers with tape and place them in a plastic bag, which serves as a secondary container. Seal the plastic bag with 2-inch masking tape.

\subsection{Absorbed tritium (applicable to NTLF personnel)}

NTLF personnel package this waste per Hanford Storage/Disposal Approval Record No. 23-1A-3J-1 instructions, as follows:

- Absorb on silica gel in polyethylene bottles.

- Package in 1-gallon cans.

- Fill cans that have more the $1 \mathrm{Ci}$ of tritium with asphalt, with at least a 1-inch thickness on all sides of the bottles.

- Seal the 1-gallon cans with a canning machine.

\subsection{Solid Transuranic Waste}

- Package the waste in 1/2-gallon or smaller ice cream cartons, with lids sealed with 2-inch masking tape.

- Place the ice cream carton inside a polyethylene bag sealed with 2-inch masking tape.

- Identify all materials on the Radioactive Waste tag by material composition (e.g., 50\% papor, $25 \%$ glass, $25 \%$ rubber). 
- Sign the waste tag; tie and tape it (with 2-inch masking tape) to the sealed plastic bag.

- $\quad$ Place the plastic bag inside a 6" diameter by 12" high metal can. (EH\&S provides the metal can.)

- Place curie amounts of transuranic materials inside a $2 R$ pipe-andnipple container (provided by EH\&S).

\subsection{Liquid Transuranic Waste}

- Evaporate the waste to near dryness inside the glove box.

- Package the nearly dry waste in LBL-certified glass containers. (Consult with EH\&S on containers.)

- Place the glass containers in the ice cream cartons described for solid waste above, and follow the solid waste procedure.

\subsection{Radioactive Mixed Waste}

The basic rules listed above apply for all mixed radioactive and hazardous wastes. That is, the rules listed above for solid compacted dry low-level waste apply to solid compacted dry low-level waste mixed with hazardous wastes. The additional task with radioactive mixed waste is to separate all radioactive mixed wastes into the hazardous waste categories listed in Appendix A. Remember that this waste is radioactive waste further contaminated with hazardous chemicals. The combination of radioactivity and hazardous chemicals makes this waste particularly difficult to handle, transport, and store, and currently impossible to dispose. Also remember that time limits apply to radioactive mixed waste. You can store radioactive mixed waste in quantities smaller than 55-gallon (drum) amounts at your laboratory for a maximum of 275 days. For drum quantities, the material must be transferred to the HWHF within 60 days of the WAA receival or accumulation start date.

A special effort should be made to minimize radioactive mixed waste. At present, it is being stored at Buiiding 75A in the HWHF. Waste that you designated as "radioactive mixed" last year is still on site and will remain on site until a national disposal site for this type of waste is approved. 
Approved By:

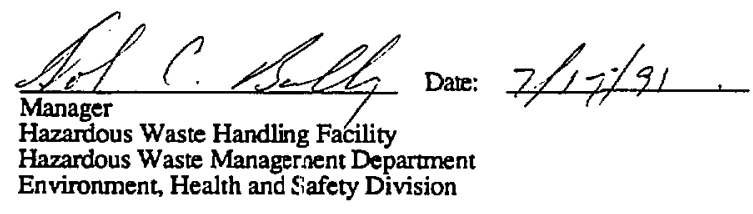

Approved By:

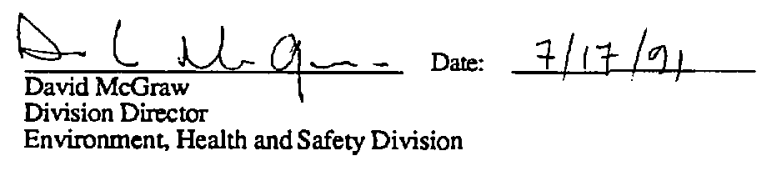

Approved By:

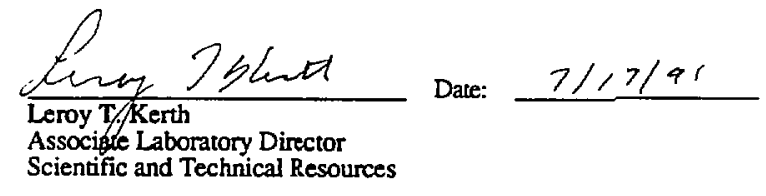


Appendices 
Lawrence Berkeley Laboratory Revises 7201

Hazardous Waste Disposal Requisition

FAX 4838 - Questions: HWHF 6146

HWHF Requisition No.

EHAS USE ONLY

GENERATOR INFORMATION-

Operating Account No.

Payroil Account

Has this information

been FAXED before?

Yes $\square$ No

Name (printec)

Department

Project

Phone

Date

Material Location (BIdg., Rm., otc.)

INSTRUCTONS: Please provide al information requested. List no more than one container per line (use additional lines to describe container contents, il needed). Use separale packing listis for each box of containerized material. Your signature is required and contifies that to the best of your knowledge, the chemical composition provided for each item is contect. Complete all entries or your request will be retumed for clarification.

1

Chomlcal Charactenzalion of Waste (Do not use abbreviations)

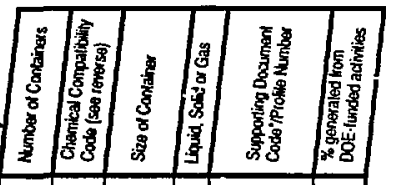

2

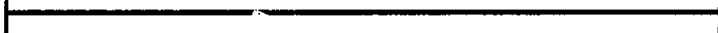

4

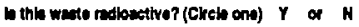

5

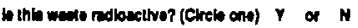

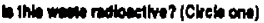

Y or $\mathrm{H}$

36

4

5

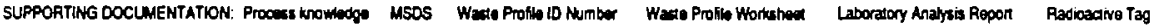

Based upon my knowledge of the waste, andjer chemientphysleal analysts, I certify that the hrormation provided rogarding the waste spectied on thls torm is correct. I understand that this information will be made available to tegulalory agencies and that there ave signifleart penalties lor subrnitting false inlormation, including the possbilty of lines and imprisonment lor knowing violations.

EHES USE OALY 


\section{Appendix A \\ Lol hazardous waste disposal packaging requirements}

The following requiremens must be mat as a condition for pick-up and disposal of chemicals by Enviranment, Haalth and Safety (EH:S). If you have questions or unusual problems, please call EHsS at extension 5251 tor assistonce.

1. Is Laboraby policy not to fluh any hazardous subsances down the LBL sewer syctem. EHBS must review and approve the dieposal of all hazardous substances to the saniany sower for complianca, es woll as for saloby issups. Weshing contaminated glassware is an example. Highly toxic, malodorous, or lachrymatory chemicals should not be disposed of down the dran. Laborabory drains are genenaly intorconnecled; a substance that goes down one sink may well come up as a vapor in enother. There is a very real hazard of chemicals from two sources contacing one another; the sulfide poured into one drain may contact the acid poured into another, with unpleassant consequences for all in the building. Some simple nactions can even ceuse expiosions (e.q., ammonia plus iodine, silver ribrate plus thanol, or picric acid pius load sals).

2. Chemicals must be separated into compatible groups. A compatibility guido is provided balow and a more dotailed version is attached tor relerence.

3. Leaking containers of any surt will not ba accepted.

4. Dy materials (gloves, wipes, pipertes, etc.) must be securely contained in double plastio bags and ovarpacked in a cardboard box. Packages that are wet or have sharp protruding objects will not bo accepted.

5. Unknown chemicals cannot be accepted by the Hazardous Waste Handling Facity (HWHF). The rasponsibla department must make every effort to identily the material designated for disposal. If al the user's attempts to identify the wasto chemicats have failod. EHES will aid in the sampling of said weste and will charge the user's account for analysis. For mpre intormation call the HWHF Maneger at extention 6146.

6. Each breakable container must be propenty boxed. Place all botres in plestic begs. Then place the bags in a sturdy container and use an absorbent cushioning material that is compatible with the chemicals.

7. Each primary conziner must be labeled with content, anount, physical state, end to percentage breakdown when dealinp with a mixture.

8. Each container must haye a complate list of contents of description writen on an official LBL Hezardous Wasie Disposal Requisition tomm. Blank torms are available trom yout division otfice.

9. Conziners must ba of a reasonable size and weight so that ons parson is able thandle them salely. Containers that exceed 45 pounds or 18 inches on a side cannot be salely handied by one person and will not be accepted. Avrangements must be made with HWHF br transpontacion of lange items.

10. Avoid accumulating laboratory chemicalsl Request hequent chemical pick-up.

11. Do not accumulate any wastes tor aver 60 days at a Wase Accumulation Area (WM) or over 275 days at a Satellito Accumulation Area (SAA).

\section{SUPPORTING DOCUMENTATION REOUIREMENTS}

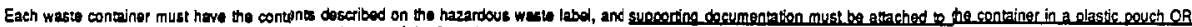
Dntie at HWHE. Supporting documentation can be one ol the following:

(A) Prosess knowledge ol wastes whose composition is documanied by the procedures genending inom; (B) recoxds of accumulation - a log that contains an entry each ime weste is added b a containgr; (C) en MSCS for ell chamicals/matorials used in an experiment or process; (D) an MSDS hor spent or unused materials; (E) a

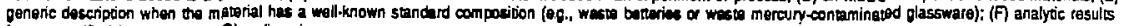

from a certified laboratory, or (G) radionctive tag.

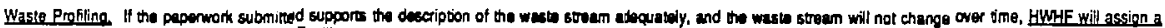

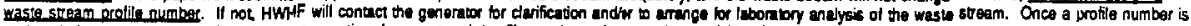
assigned, the generesor enters it under the supporting dosument codejprofile number colum on the requition lom.

\section{PCXUP AND TRALSPORTATION}

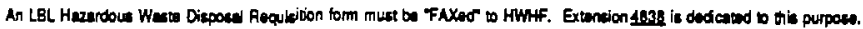

Keap two copies of the requicition form; athech one copy to the containers b be picked up and put the other in youp file or work binder as a generator recerd.

\section{CHEMICAL COMPATEILITY GUIDE}

Separating chemicals into compatible groups can be a complicated procadure. Thare at stveral in-depth guides available. For the purposes of packaging chemicals for

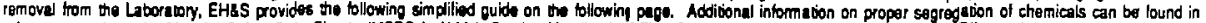

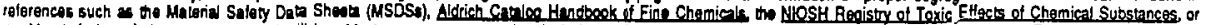

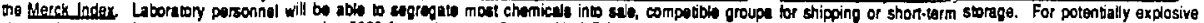

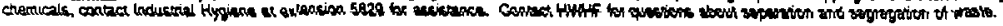

CHEMICAL COMPATIBILITY CODES

\section{Solvents - Flammable Liquida, Combusbbia Liquids}

II. Fammabie Solids - Organie, Mabuls, Solide ghat ere dangurous when wah Sulfiden. Phosphoreus Allotopes, Organomotalic Compounda, inorgania

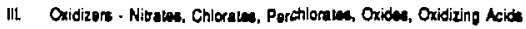

IV. Corrosives .

Acids (Minerd, Organic, Arectiva Conosives):

Bace (Inomanics, Opganics, Hydazins Solutions)
V. Poisone - Organies, Babllics, Inorganic Cyanidas

VI. Pounbal Auactives (Explosive) - Trinitros, Azides, Amides, Monomeric leocyanates

VIL Othar Chomical Westo - Separato organics horn inorganics. Separate liquids trom colide

Vill. Dabria - Sopanto organics from inorpanics and labal packaging with all conaninanis present? 
Identifying and recognizing the hazards of each chemical is critical in order to handle these materials safely.

To meet safety and environmental requirements, the following basic categories must be used for segregating and separating your waste.

I. Solvents

A. Flammable Liquids

1. Aliphatic:

Acetone, Isopropanol, Methyl Ethyl Ketone, Methanol

2. Aromatic:

Toluene, Xylene, Benzene, Propyl Benzene

3. Monohalogenated Solvents:

4. Monomers:

Chlorobenzene, Ethyl Chloride, Acetyl Chloride

5. Reactives:

Styrene, Ethylene, Vinyl Acetylene, Vinyl Pyridine

Isopropyl Ether, Phenyl Manganese Chloride, Hydrazine Anhydrous, Ethyl Ether, Divinyl Ether

B. Combustible Liquids

1. Glycois:

2. Mineral Spirits

Ethylene Glycol Dibutyl Ether, Ethylene Glycol Monomethyl Ether

C. Halogenated Solvents

Carbon Tetrachloride, 1,1,1-Trichloroethane Ethyl Chloroacetate

11. Fammablo Solids

A. Organic Flammable Solids:

B. Flammable Motals:

Cellulose Acetate, Nitrocellulose (At least $20 \%$ wot)

Manganese, Magnesium, Ytrium, Zirconium

C. Flammable Solids (Dangerous when wo1):

D. Flammable Sultidos:

Sodium, Lithium, Calcium, Lithium Hydride

E. Phosphorous Allotropes:

Phosphorus (Yellow, Red, White), Aluminum Phosphide. Phosphorus Sultide,
Phosphorus Pentasulfide

F. Organometallic Compounds:

F. Lithium Butoxide, Lithium Matoxide, Sodium Ethoxy, Sodium Butylate, Potassium Mothylate

G. Inorganic Flammable Solids:

Sodium Phosphide. Aluminum Hydride, Sodium Borohydride, Boron Lithium Aluminum Alloy

ill. Oxidzers
A. Nitratos:
B. Chlorates:
C. Perchlorates:
Potassium Nitrate, Calcium Nirrate, Sodium Nirrate, Zine Nirrate, Thallium Nitrate
D. Oxides:
E. Oxidizing Acids:
Lithium Porchlorato, Magnesium Perchlorate
Potassium Chlorate, Lithium Chlorate, Calcium Chlorate, Strontium Chlorate
Manganese Dioxide, Magnesium Dioxide, Chromium Trioxide, Lead Oxide (Brown)
Nitric Acid (greater than 40\%), Porchloric Acid, Periodic Acid 
A. Acids

1. Mineral Acids:

Hydrochloric Acid, Sulfuric Acid, Nitric Acid (Less than 40\%), Phosphoric Acid

2. Organic Acids:

Acetic Acid, Acetic Anhydride, Acetyl Bromide, Formic Acid, Iscpentanoic Acid

3. Reactive Corrosives:

Phosphorus Trichloride, Phosphorus Pentachloride, Antimony Trichloride, Phosphoric Anhydride

B. Basos

1. Inorganics:

Sodium hydroxide, Potassium Hydroxide, Ammonium Hydraxide, Sodium Hypochlorite

2. Organics:

Amino Propyl Diethanolamine, Amino Ethyl Piperazine, Acetyl lodide, Benzoyl Chloride,

3. Hydrazine Solutions

v. Polsons
A. Organics:
B. Metallics:
Phenol, Acrylamide, Benzoin, Benzidine, Aniline
c. Inorganic Cyanides:
Arsenic, Load, Beryllium, Mercury, Selenium
Potassium Cyanide, Sodium Cyanide, Cyanogen Eromide

VI. Potentlal Rasetwes (Explaske)
A. Trinitros:
B. Azides:
Trinitrophenal (Picric Acid), Trinitrobenzone, Trinitrotoluene (TNT), Trinitromethane
C. Amides:
Hydrogen Azide, Ammonium Azide, Barium Azide, Chlorine Azide, Silver Azide
D. Monomeric Isocyanates:
Trinitroaniline (Pictamide), Sodamide, Potassium Amide
Hydrocyanic Acid, Isothiocyanuric Acid

VII. Other Cherrical Waste
A. Separate Organics from Inorganics*
B. Separate Liquids trom Solids

Vill, Dobrite

A. Separate Organics trom Inorganics* and label packaging with all contaminants present.

"Inorganic materials contaminated with organic components should be segregated as organic. 


\section{Appendix B: Profiling Wastes}

\section{Introduction}

If you have a waste-generating operation that produces a number of waste containers having the same composition, you can establish proper identification for all waste containers through a process called "profiling." Profiling will avoid the cost and delay of anayzing the waste in each container.

Profile forms can be obtained from the Hazardous Waste Handling Facility (HWHF). To complete the form, you identify and quantify all of the possible waste components in the particular waste container. To confirm this information, you must submit a detailed laboratory analysis, and/or a Material Safety Data Sheet (MSDS).

HWHF personnel will review the profile application and issue an "approved profile" with its own unique number. The profile number may then be entered in place of the analysis sample number whenever that waste is identified on a Hazardous Waste Requisition Form. The waste description as written on the profile sheet must still be copied onto each requisition in order to identify the package of material. A profiled waste will be accepted by the HWHF wirhout a complete analysis for each waste container. Any change in the process affecting the composition of the waste must be reported to the HWHF so that the profile can be changed. Profiled wastes are randomly analyzed as part of the HWHF Quality Control program (see the Waste Analysis Plan, Pub-5309). Unreported changes in composition of the waste will result in loss of profiling privileges, so that each waste container will have to be analyzed completely prior to waste pickup.

There are nine sections on the four-page profile form. The first five sections on the first page of the form must be filled out for all wastes. Sections 6 through 8 pertain to information required for specific waste types. Section 9 is for additional information or comment on the particular waste, or overflow space for information required in another section. Copies of analyses and MSDSs (for commercial products only) must accompany the profile. Historical analyses can be used to profile a waste if substantiated by analytical laboratory records. A copy of this form is shown at the end of this Appendix.

\section{Section 1}

Identify the program, project, or facility, and person responsible for the process that generates the waste stream. Please provise the proper phone number and account number. The person in the Environment, Health and Safety Division who is advising you is your HWHF contact.

\section{Section 2}

Identify the waste with a basic description. Be as specific as possible (e.g., ferric chloride etchant, Kodak Microfilm Bleach, Catalog No. 180-3972). Liquid waste is not an adequate description. Aqueous liquid waste may suffice in some instances, but as a first step in this case, list the solutes and their concentrations.

Identify the process producing the waste. Be as specific as possible (e.g., printed-circuit etching bath, photographic $B / W$ reversal process). Estimate anticipated amounts of waste per appropriate time period (e.g., pounds per year, gallons per month, kilograms per year). Physical Description: check applicable description (Sections 6 through 8 of form) for 
required analysis. Go to applicable sections on the following pages to determine which chemical analyses need to be performed.

\section{Section 3}

All radionuclides and their amounts in grams or curies must be listed for each container on the requisition. Estimates can be based on knowledge of the waste-generating process, historical analytical data, etc.

\section{Sectior، 4}

Check (or list, if not on checklist) all applicable hazardous characteristics.

\section{Section 5}

List the chemical composition of the waste as completely as possible.

List the components as they would be found in the waste. Be sure to correct for dilution or other changes that may have occurred.

For commercial products and formulations, include the list of hazardous ingredients from the MSDS. Be sure to correct for dilution or other changes that occurred as the product was used. (Attach page 1 of MSDS to profile.)

Concentration ranges are meant to be used for actual varitions in the waste composition.

List all possible hazardous process contaminants with estimated ranges of concentration. These must be substantiated by chemical analyses. (Include copies of analyses.) Historical analyses, if available, are ideal for this purpose since they give a range of values. If no historical analyses are available, analyze the waste stream completely to substantiate estimated ranges

See sections unde: "physical description" for required ranges. Include these when applicable. Include this requred information in the "composition" section.

\section{Sections 6-8}

These sections contain required analyses for specified types of waste. Starting with the physical description portion of Section 2, proceed to the indicated section $(6,7$, or 8 ). From the selection guide at the start of the section $(6,7$, or 8$)$, select the subsection $(6,7,8 \mathrm{~A}, 8 \mathrm{~B}, 8 \mathrm{C}$, or $8 D$ ) that describes the waste. Fill out any required analyses at the head of the section.

Proceed to any specific subsection indicated, and fill out the required analytical information. Copy this information, with ranges, onto the chemical composition section on page 1 of the form.

\section{Section 9}

This section is for any additional information or comments on the waste stream. Additional information from other sections should be placed here. 
Profila Number

(To be filled in by HWHF)

Acoount Number.

Data

\section{LAWRENCE BERKELEY LABORATORY WASTE PROFILE WORKSHEET \\ (FOR REPETITIVE WASTE STREAMS OF UNCHANGING COMPOSITION)}

\section{Sections 1 through 5 must be completely filled out}

1. Program/Project /Facllity

Bunding

Peom

Responsible Person

HWHF Contad

Prone.

2. Waste Description:

Process Producing Waste

Physical Destcription:

$\square$ aqueous liquid (fill out sec 6) $\quad$ ) colants (fill out sec 7C)

Amicipated Rate

$\mathrm{yr} / \mathrm{mo} / \mathrm{wk}$

$\square$ organic solvents and incinerable liquid waste (iill ovt sec 7A)

D multiphase - treat each phase separate ly (fill out secs 6 and 7 )

$\square$ solids and sludge (fill out sec 8) $\square$ respirabte tine powder $\square$ compressed gas or volatile liq.

3. Radloactive: (list range of ALL radionuclides in curies or grams)

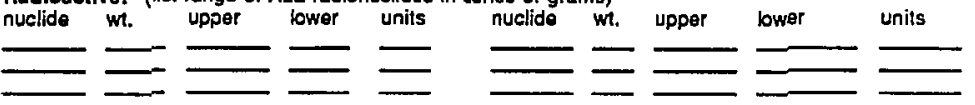

4 corrosive acid $\square$ corrosive base $\square$ water reactive $\square$ toxic $\square$ flammable $\square$ combustible $\square$ pyrophoric $\square$ biological $\square$ explosive $\square$ compressed gas $\square$ Oher

5. Chemical composition:

List range of all known components and contaminants

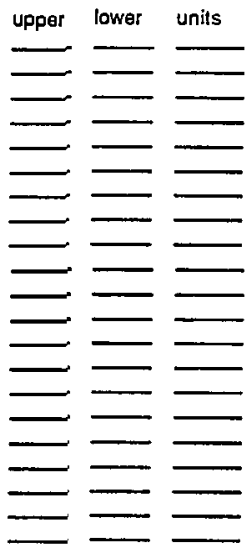


6C. Phatoprocess Wastes: (process step)

$\square$ developer $\square$ stop bath $\square$ fixer $\square$ ioner $\square$ reducer $\square$ final wash $\square$ reversal bath Dbaach $Q$ hardener

normality/molarity or $\mathrm{pH}$ (pH 2 to 11 by mater or 3 to 11 paper)

silver gpm chromium opm reducer: zinc opon remer platlinum ppm

selenium ppm other ppm ppm

6D. Metal Finlahing Wastes (including wash waters)

hazandous metal lons (ist ALL components and passible contaminents) boll disolved and suspended metals:

beryllium (Be]____ Ppm

chromium $(\mathrm{Cr}) \_$pam

copper (Cu)__ ppm

assenic (As)__ Ppm

cyanio __. Ppm

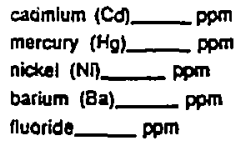

lead (Pb)___ Ppm

zine (Zn)___ Ppm

sitver (Agl___ Ppm

Others:

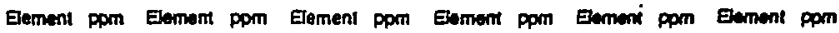

$\longrightarrow \longrightarrow-$

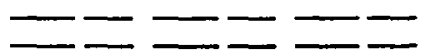

7A. Organie Solvent and Inclnerable Llquid Waste:
Atastipoint of lobal orpanic halogen
then of combustion
solal nitrooen
botal sulther.

Does the waste contain the following meterials?

Dore than 100 pom of AWY cyanide, nitrils, isocyanate, or cyano rasin

Q ANY heary metal organomelatice (ie. chromium cetoate, phenyt mercury)

organic peroxiods

more than 2 pom polychiorinated biphenyls (PCB's)

Q organic material with 3 or more "nitro" groups

Q large emounts of horgank anions such as sultate

78. Olis: (silbome compounds are not oils and should be listed as huids)

total organic thalogen Dam polychlorinated blphents (PCB's) ppm

7c. Coolenta:

lotal organk halogen Dom oil * (by extracion)

Matal conlaminents in equeous phese: (fist ALL possible contaminants) Elamenl ppm Eement pprn Elamem ppon Elomem ppm Element ppm Eement pom

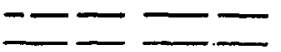

Gross radioactvity: atpha HCV $1000 \mathrm{~L}$

betz $\mu \mathrm{Ci} 1000 \mathrm{~L}$

trillum HCiv1000 L 
8. Solids and Sludge:

sludges: frea liquids \% by weight

Hazardous and/or radioactive mixed solid wastes require EP TOX:

Q pass compression test

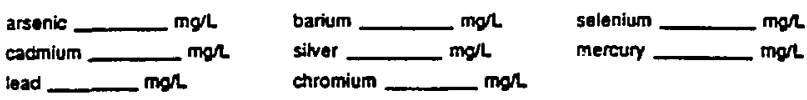

Toricity characteristic leaching procedure (TCLP): (crect contaminants)
Q acrylonitrile
G carbon telrachloride
o.m.p cresol
C. 1.2 dichloroethane
hexactilorobenzene
isobutanol
melinyl ethyl ketone
phenot
roluene
C. tichlorosthytens
1,1,2 irichlorcethane
2.4.0 irichlorophenol
bis (2-ehloroethyl) : ether
chiorobenzene
1,2 dichlorobenzene
1.1 dichloroethylene
maxachlorobutadien:
methoxyctior
nitrobenzene
pyridine
1.1.1.2 ietractioroethane
1,1,2,2 tatractionowthene
2,3.4,6 tetrachinrophenot

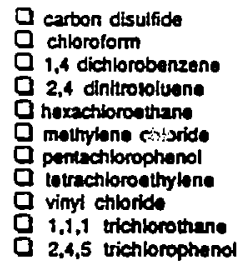

9. Additional information or comments: 
Appendix C: Who to Call for Further Information

Number

$\underline{\text { Item }}$

Person

5251

5829

4644

7625

6146

7623

4644

7625

6146

7625

6242

4644

7625

6146

4838

4776

6015

6146

6146

6146

6146

5829

6146

5303

6146

7625

6146

7625

7615

EH\&S general number Industrial Hygiene Department general number

Environmental Specialist

HWHF Technician

HWHF Manager

Fnvironmental Monitoring

Help in locating WAAs

Help in locating WAAs

Help in locating WAAs

Absorbant for spill cleanup

Chemicals, solvents, surplus

Compatibility, chemical (what can be stored next to what and where)

Compatibility, chemical

(what can be stored next to what and where)

Containers for hazardous waste (what type to use)

Fax number, hazardous waste disposal

Fax number, EH\&S

Grounding and bonding wires

WAA Daily Inspection Checklist

WAAs, establishing or deactivating

WAA site record-keeping requirements

WAA site guidelines for maintenance

Hazardous material, information prior to ordering

Hazardous waste not picked up in 3 days

Lead, scrap, not contaminated

Labeling "empty" hazardous waste containers

Labeling "empty" hazardous waste containers

Labeling hazardous waste containers

Labeling hazardous waste containers

Liquid destined for EBMUD sewer
Rita Cummings

Reggie Martinez

Charlie Carr

Gary Schleimer

Rita Cummings

Reggie Martinez

Charlie Carr

Reggie Martinez

Materiel Management

R.ita Cummings

Reggie Martinez

Charlie Carr

Fire Department

Charlie Carr

Charlie Carr

Charlie Carr

Charlie Carr

Industrial Hygiene

Department

Charlie Carr

Salvage

Charlie Carr

Reggie Martinez

Charlie Carr

Reggie Martinez

Charles Smith 
Number

5829

4644

7609

7625

5303

5303

4644

4644

7625

5829

7603

7621

4644

4644

7625

5251

5258

4644

6266

7911

7911

1-800-523-2222

1-415-476-6600
Item

Person

MSDSs, copies of

MDSDs, interpretation of

Mercury, spill

Mercury, spill

Metal, precious, recycling of

Metal, scrap, for recycling

Minimizing hazardous waste in your area

Mixing waste (what's safe to mix?)

PCBs, disposal of

PPE (Personal Protective Equipment)

Radioisotope safety

Radioisotope transportation

Regulations, hazardous waste, clarification of

Regulations, hazardous waste, copies of

Spill cleanup supplies

Training, to sign up for

Training, hazardous waste, course content

Training, medical and biological waste, course content

Chemical exposure (skin, hair, eyes, swallowed, inhalation)

Chemical exposure (skin, hair, eyes, swallowed, inhalation)
Industrial Hygiene Department

Rita Cummings

Glenn Garabedian

Reggie Martinez

Salvage

Salvage

Rita Cummings

Rita Cummings

Reggie Martinez

Industrial Hygiene

Jim Haley

Dick Harvey

Rita Cummings

Rita Cummings

Reggie Martinez

EH\&S front desk

Jack Bartley

Rita Cummings

Medical Services

(normal working hours)

Fire Department

(off hours)

\section{Hazardous Material Spills}

Poison Control Hotline for help with chemical exposures Poison Control Hotline for help with chemical exposures 
Appendix D

\section{Forms}




\section{LAWRENCE BERKELEY LABORATORY RECORD OF WASTE ACCUMULATION}

\begin{tabular}{|c|c|c|c|}
\hline $\begin{array}{c}\text { DATE } \\
\text { ADDED }\end{array}$ & DESCRIPTION OF WHAT WAS ADDED & AMOUNT & INITIALS \\
\hline & . & & \\
\hline & & & \\
\hline & & & \\
\hline & & & \\
\hline & & & \\
\hline & & & \\
\hline & & & \\
\hline & & & \\
\hline & & & \\
\hline & & & \\
\hline & & & \\
\hline & & & \\
\hline & & & \\
\hline & & & \\
\hline & & & \\
\hline & & & \\
\hline & & & \\
\hline & & & \\
\hline & & & \\
\hline & & & \\
\hline & & & \\
\hline & & & \\
\hline & & & \\
\hline & & & \\
\hline & & & \\
\hline
\end{tabular}


HWHF REQ. No.

SAMPLE I.D.

OPERATLNG ACCT NO. DATEOFREQUEST:

For E\&SHC use only

Sample Taken By:

Date Sampled:

Method of Sampling:

Date Sent to Lab:

Date Analysis Rec'd:

\section{GENERATOR/SURMITTER_INEORMATION}

NAME:

PAYROLL ACCT:

MAILSTOP:

EXT:

SAMULE_INEORMATION

LOCATION (BIdg., Room): CONTACT PERSON:

EXT:

Type of Container

SUSPECTED CHIEMKAL COMPOSTION \& DESCRIOTION OF PROCESS OR EXPERIMENT ORIGIN IN DETAIL

(E.G., PHOTOGRAPHIC, ETCHING, HUMAN GENOME, CHROMATOGRAPHY, ETC.)

(Atlach additional sheet if necessary. Precise information minimizes the cost of analysis.)

\section{INDICATE THE SUPRORTING DOCUMENT THAT IS ATTACHED:}

D MSDS for each constiuent

Dormulation(s)

Chemical composition

Record of how the waste was accumulated in the container (date, what was added, the amount and initials for each addition)

$\square$ Olher

\section{THE_SAMRLE_IS POTENTUALY:}

$\square$ carcinogenic $\square$ conosive $\square$ explosive $\square$ flammable $\square$ an oxidizer $\square$ poisonous $\square$ radioactive $\square$ reacive

\section{RADIOACTIVE INFORMATION}

- Radionuclide(s):

Activity:

Methods of Assay:

Performed By: Dace: 